\title{
Using Real Options for the Evaluation of Venture Projects
}

\author{
Alexander Baranov, ${ }^{1}$ and Elena Muzyko $^{2 *}$ \\ ${ }^{1}$ Faculty of Economics, Novosibirsk National Research State University; Institute of Economics and \\ Industrial Engineering, Siberian Branch of Russian Academy of Sciences, Novosibirsk, Russia \\ ${ }^{2}$ Faculty of Business, Novosibirsk State Technical University, Novosibirsk, Russia
}

\begin{abstract}
This paper considers the peculiarities of the application of the real options method for assessing the economic efficiency of venture investments in innovative projects from the venture fund's position. The results of the practical use of the author's approach for the evaluation of venture investments with real options are analyzed. The paper shows the applicability of the real options concept to the valuation of the effectiveness of venture capital investments. The use of the real options method raises the accuracy of the estimation and enhances the instruments of the venture fund in evaluating the economic efficiency of innovative projects.
\end{abstract}

Abstrak: Artikel ini membahas kekhasan aplikasi metode real options untuk menilai efisiensi ekonomis investasi ventura dalam berbagai proyek inovatif dari posisi dana ventura. Hasil penggunaan praktik pendekatan penulis terhadap evaluasi investasi ventura dengan real options dianalisa. Artikel ini menunjukkan aplikabilitas konsep real options untuk penilaian keefektifan investasi modal ventura. Penggunaan metode real options meningkatkan akurasi estimasi dan menambahkan instrumen dana ventura dalam mengevaluasi efisiensi ekonomis proyek inovatif.

Keywords: financial options; innovative project; real options; uncertainty; venture capital investment

JEL classification: G24; G32; M13

* Corresponding author's e-mail: mei927@mail.ru 


\section{Introduction}

With current financial theories, traditional approaches to the assessment of the efficiency of investment projects very often show their limitations, since most of them are not suitable for projects implemented in conditions with high risk and uncertainty. Traditional discounted cash flow analysis (the NPVmethod) is based on the assumption that after making a decision on starting an investment project, the management should follow the initially chosen strategy even in adverse circumstances. However, after starting the project's implementation, the company's management can change the initial plan, for example, to expand or constrict the scope of the project, change the "inputs" or "outputs" of the project, abandon further implementation of the project, or "freeze" it for a certain period of time, once new information becomes available.

In this regard new methods of valuing innovative projects become particularly important. Among such instruments is the real options method. The most important feature of this method is its compliance with the rapidly changing economic environment in which a company operates, as well as taking into account the company's managerial flexibility in making decisions. The real options theory can explain the fact, which is known from practice, that investors often do not abandon projects with a negative NPV (Net Present Value), as the situation may change for the better, and the real option, which is incorporated in the innovative project, can be used. As a result, the net present value of the project will be positive.

The real options concept has developed as a result of the transfer of risk management instruments, that use option contracts, from the financial sector to the real sector of the economy. The real options theory is an alternative view on investments and projects' effectiveness valuations. The basis of the theory is the assumption that it is possible to present an investment project schematically as a financial option.

A financial option is a contract, which gives the buyer (or the owner) the right, but not the obligation, to buy or sell an underlying asset or instrument at a specified strike price on or before a specified date. A real option is an option on a non-financial asset. The underlying asset of the real option is the cash flow of the investment project.

As venture capital investments are characterized by high risks and high returns, and they often have a phased nature, the traditional NPV method can be supplemented by other methods, which allow a more accurate valuation of the effectiveness of risky projects to be obtained. Meanwhile the existing valuation models of real options have certain limitations in their application for the purpose of assessing venture investments.

In the article the following results were obtained:

1. The peculiarities of the application of the real options method for assessing the economic efficiency of venture investments in innovative projects from the venture fund's position were determined.

2. The author's modification of the real options method for the valuation of venture capital investments from the venture fund's position was approbated using data on venture projects in the industrial sector in Russia. The practical effectiveness of this approach was demonstrated.

3. The application of the real options method to assess the efficiency of investment projects in Russia is very limited. Unfortunately, this method is not widely used by 
Russian financial managers. It is known from experience that only one investment company uses this method ("Laboratory of investments "LABRATE"). Therefore one of the objectives of our research was the extension of the practical use of the real options method for project analysis in Russia. So, for this case we have taken Russian innovative project in the industrial sector and have estimated it's effectiveness by the order of the initiators.

\section{Literature Review}

In Russia there are separate works on venture capital financing and real options. But no research has been done concerning the application of the real options method to the venture capital financing of innovative projects up to now. We will analyze the work of foreign scientists concerning this problem, unfortunately the amount of such research work is quite limited.

According to which way is chosen of using the real options method in venture capital investing, the papers analyzed by us can be split into four groups. We will begin our analysis with considering the papers of the first group. Botteron and Casanova (2003) proposed an option pricing model that made it possible to evaluate the flexibility acquired by a venture capitalist when he staged his investment process. The authors consider the start-up value as a value of two options, namely, a European call-option and a European binary call-option.

The formula developed by Black and Scholes (1973) to value a European call-option and the formula proposed by Geske (1979) to value a two-stage compound European call-option can be applied only in the case of the constant volatility of the underlying asset's value. Hsu in his work (2002) modified these formulae to evaluate options with timedependent volatility. In this paper the process of decision-making by a venture capitalist to invest in the staged manner is analyzed in the light of the principal-agent problem. A venture capitalist can invest up front in the form of a one-time fixed amount or he can cut his investment into several stages. Staged investment is treated as a compound European calloption with time-dependent volatility. To assess the value of this option Hsu (2002) modified the Geske's formula. Venture financing involving a one-time fixed amount is treated as a straight European call-option but with time-dependent volatility. To assess the value of this option the author modified the BlackScholes formula (Hsu 2002).

Gong et al. (2006) proposed a model of the elementary compound options valuation. They introduced time-dependent volatility into the model of valuing a multistage compound real option based on the model of valuing a multistage compound real option with constant volatility, as proposed by Lin (2002). Willner (1995) proposed to value a start-up as a real option. To determine the dynamics of changing the underlying asset value, the Poisson process instead of the Winner process was used in the model.

Let us make a critical analysis of the papers. Botteron and Casanova's (2003) paper stated that a venture project (a start-up is nothing else than a project) was an underlying asset. In our opinion the underlying asset is not the whole venture project but a portion of the shares of the investee company, since a venture capitalist owns only a portion of the shares but not the whole project (start-up).

In his paper, Hsu (2002) does not give an interpretation of the Black-Scholes formula elements. In all the reviewed papers the analysis is made in terms of a venture project as a 
whole. The cash flows of the venture capitalist and the cash flows of the project itself are not separated. No approbation of the proposed models of assessing the options value based on real innovation projects with venture financing is made in the papers considered above. A common feature of the papers of the first group is a high degree of mathematization while any economic interpretation of the parameters included in the proposed models of valuing real options in venture financing is not given.

Let us consider the second group of papers. In their paper, Huixia and Tao (2010) used a binomial model of option valuation in the case of venture financing, with the focus being on American-style options. However, the peculiarities of venture financing are not analyzed. It is not explained why it is the binomial model that is chosen for the venture financing case. Any approbation of the binomial model based on real data from innovative projects with venture financing is not made. Seppa and Laamanen (2001) arrived at the conclusion that the binomial model was more appropriate for the valuation of venture capital investments than the traditional method of discounted cash flow.

Let us now analyze the third group of papers. In Li's (2008) paper, the decision to stage the investment process is viewed as a choice between holding an option on investing later (an investment delay) and investing now to obtain an option on further staged investment. The authors Tong and Li (2010) claimed that when making initial investments, venture capitalists obtain an option on expansion, an option on the project abandonment and an option on an investment delay. We believe that in the venture financing of innovative projects, all these three types of real options could be combined into one type, namely the compound call option on staged investment, which will reflect the specificity of venture financing.

Wadhwa and Phelps (2010) in their paper characterized corporate venture financing as a two-stage compound option. An initial venture capital investment created a compound growth option. Forming a strategic alliance with a portfolio company was viewed as exercising the second stage of this option.

Let us move to the last or fourth group of papers. Vanhaverbeke et al. (2008) analyzed the advantages of external corporate venture financing as "open innovation practices" in terms of the real options. They claimed that it was necessary to take into account the value of the real options but they do not explain how to assess this value or by using what models.

The authors of the papers in the fourth group (Vanhaverbeke et al. 2008; Kulatilaka and Toschi 2011) wrote about the usefulness of the real options theory in the analysis of venture financing, but they confined themselves to detailed verbose reasoning without making any analysis of models of the real options valuation that emerged in the venture financing of investment projects. Besides, they do not make any calculations

Also let's make a brief review of other studies, in which the authors apply Geske's formula to compound real options valuations in multi-stage investments. Carr (1988), building on Margrabe (1978) and Geske (1979), provided the valuation of sequential exchange options. Lee and Paxson (2000 a) suggested a two-point confined exponential extrapolation method for the American option, by extending Geske and Johnson's (1984) compound option approach. The value of such an American sequential exchange option is given in Lee and Paxson (2000 b). Lee and Paxson (2001) in their work modeled the stages of R\&D ex- 
pense and the ultimate discovery using real sequential (compound) exchange American option models.

Herath and Park (2002) investigated a multi-stage project setting, where each investment opportunity derived revenues from different markets but shared common technological resources. They extend the binomial lattice framework to model a multi-stage investment as a compound real option. Jensen and Warren (2001) in their paper examined the practicalities of applying the real options theory to valuing research in the service sector, where the relationship between research and subsequent business benefits is less easily discerned than in most previous applications of the options theory in, e.g. the pharmaceutical industry. The paper used a compound options model, the Geske model, based on a three-phase lifecycle consisting of research, development and deployment. All these papers had a high degree of mathematization, while any economic in-depth interpretation of the parameters included in the proposed models of valuing the real options was not given.

Having made a critical survey of the studies in which the real options method was used in analyzing the venture financing of investment projects we can make the following conclusions. In Russia not many researchers are now working on this problem. However, studies concerned with the use of the real options method for the evaluation of the efficiency of investment projects with venture financing, carried out by foreign researchers are also scarce. In these papers any economic interpretation of the parameters included in the proposed models of the real options valuation that emerge in the venture financing of investment projects is often not given. In all of the reviewed papers the analysis has been done from the point of view of the invest- ment project as a whole. In our opinion, it is necessary to separate the cash flows of the venture fund and the cash flows of the project itself. A venture fund has its own cash flows, which are different from those of the entire project under analysis. An approbation of the proposed models based on real innovation projects with venture financing is not made. To our mind the case for a venture capital investment is a compound real call option with time-dependent volatility.

\section{Methods}

Venture capital investments are characterized by high risk levels and high uncertainty, and they often have a phased nature. Moreover, each phase of a venture investment has its own risk level. So, the model, which could be used for the valuation of the real options in the venture financing of innovative projects should take into account the different levels of risk at the different phases of the investment.

Geske (1979) created a formula for the evaluation of the two-stage compound European call-option. But Geske's formula can be applied only in the case of the constant volatility of the underlying asset's value. Hsu in his work (2002) modified this formula to evaluate options with a time-dependent volatility (the modified Geske's formula).

In this paper we used the modified version of Geske's formula, but we have changed the sense bearing understanding of the entry parameters of the model. We believe that when assessing the value of the real options in a venture capital investment, it should be taken into account that there are differences between the cash flow of the entire innovative project and the cash flow of the venture fund. For instance, the venture fund's investment may 
be less than the investment for the entire project. Positive cash flows for the venture fund are less than the positive flows for the entire innovative project. Thus, we are considering the economic efficiency of venture investments in innovative projects from the venture fund's position. Figure 1 shows a schematic representation of the venture investment buying a share purchase call option at the beginning of the investment process.

Let's appraise the efficiency of the innovative project from the point of view of the venture fund, both by the traditional method of the discounted cash flow (a standard calculation) and using the real options method. We will now describe the suggested procedure in detail.

The first step is to determine the innovative project's efficiency from the viewpoint of the venture fund using the traditional method of discounted cash flows. This step includes an estimation of the cash flows of the venture fund, it's net present value and the inter- nal rate of return (NPV $V^{v}$ and $I R R^{v}$ respectively) for different variants of the venture fund's share in the charter capital of the investee company (starting from $25 \%$ with a step up of $4 \%$, for shares of $29 \%, 33 \%, 41 \%, 45 \%$, $49 \%$ ) and different values of the price-earnings ratio for the shares $(\mathrm{P} / \mathrm{E}=2,3,4,5,6$, 7).

The second step is to determine the innovative project's efficiency from the viewpoint of the venture fund by using the real options method (an estimation taking into account the value of the compound call option). This step includes the following: An estimation of the internal rate of return of the venture fund $I R R^{v}{ }_{\text {option }}$ and the net present value of the venture fund $N P V^{v}{ }_{\text {option }}$ taking into account the value of the compound call option as an additional cash flow, which appears at the very moment of the venture fund's "exit" from the business of the investee company.

The compound call option for the venture fund with a changed sense bearing un-

Figure 1. A Schematic Representation of a Venture Investment by Buying a Share Purchase Option at the Beginning of the Investment Process

\begin{tabular}{|c|c|c|}
\hline $\begin{array}{l}T_{0} \text { is the time when a ven- } \\
\text { ture fund buys a com- } \\
\text { pound call option at the } \\
\text { price } I_{0}^{v} \text { to purchase a } \\
\text { portion of the shares of } \\
\text { the investee company at } \\
\text { the time } T_{1} \text {. }\end{array}$ & $\begin{array}{l}T_{1} \text { is the time of purchasing a } \\
\text { portion of the shares of the } \\
\text { investee company at the price } \\
I_{1}^{v} \text {, i.e. the exercise of an exter- } \\
\text { nal option, which means the pur- } \\
\text { chase of an internal option on } \\
\text { making a profit on selling the } \\
\text { shares of the investee company } \\
\text { at the time } T_{2} \text {. }\end{array}$ & $\begin{array}{l}T_{2} \text { is the time of selling } \\
\text { the shares held by the } \\
\text { venture fund, i.e., getting } \\
\text { assets in the form of the } \\
\text { profit from selling the } \\
\text { shares of the investee } \\
\text { company at the price } \\
\boldsymbol{I}_{2}^{v} \text {. }\end{array}$ \\
\hline
\end{tabular}


derstanding of the entry parameters could be estimated with a developed version of the Geske model (see formula (10.1), Appendix 10). As the size of the paper is limited the detailed definitions of all parameters are given in Appendix10.

Now we will describe the technique of the compound call option's estimation in detail. The critical value of the investee company's equity shares at the moment $T_{1}$ can be found from the equation (10.2) (see Appendix 10).

It should be said that as the venture fund usually has a portfolio of investment projects, stopping its investment, at moment $T_{1}$ in the project will allow the venture fund to reallocate its limited resources to other projects. In our interpretation, the value $V_{T 1}$ is the evaluation of the business at the moment $T_{1}$ :

$$
V_{T_{1}}=N P A T_{T_{1}} \cdot P / E
$$

To obtain the $V_{T 1}^{v}$ the value $V_{T 1}$ is multiplied by the fund's share. There is no analytical solution of the equation (10.2). So, to find the figure for the critical value of the investee company's equity shares at moment $T_{1}$ it is necessary to use an optimization method. Such optimization procedures as Newton's method and the conjugated gradient method are realized in Microsoft Excel. Since these methods give practically the same result, we can use either of them.

Selling the shares at moment $T_{2}$ the venture fund will lose the current period's profit in proportion to its share of the charter capital in the investee company. We consider this figure to be its implicit costs and the exercise price of the internal call option:

$$
I_{2}^{v}=N P A T_{\text {total Exit }} * S \text {. }
$$

where $N P A T_{\text {total Exit }}$ is the net profit (total) in the year of the "exit" by the venture fund from the business it invested in; $S$ is the share of the venture fund in the charter capital of the investee company.

The current value of the underlying asset in our interpretation is the current value of an equity share of the investee company, which is owned by the venture fund $\left(V^{\prime}\right)$. It is the evaluation of the income that the venture fund will get from the sale of its shares.

The risk-free interest rate $r$ in our calculations will be 7 percent. This figure is taken as an average of deposit rates for alternative assets like long-term deposits in the largest and safest Russian banks as on 19.09.2011 ("The Rosselkhozbank," "The Sberbank of Russia," "Gazprombank," and the "VTB Group"). $\sigma_{1}$ is the variability index of the NASDAQ Biotechnology Index (NBI) over a 7 year period (from 14.10.2004 to 14.10.2011) (NASDAQ Biotechnology Index. URL:http:// w w w. nas d a q. com/dy na m ic / nasdaqbiotech_activity.stm. Date of access: 09.09.2011). It was also decided to use the NBI index over a 7 year period and not just for the last year only, because this 7 year time period included the World financial crisis $(2007,2008$ and 2009). The standard deviation of the NASDAQ Biotechnology Index equals 15.44 percent. The variation coefficient of the NASDAQ Biotechnology Index will be 12.78 percent. Thus, $\sigma_{1}=12.78$ percent.

The compound call option value is practically independent on the $\sigma_{2}$ values. No significant impact of $\sigma_{2}$ on the value of the compound call option is explained mathematically from the formula (10.1, Appendix 10). In equation (10.1) $\sigma_{2}$ is included in the first additive component as a parameter, that influences the value of $N_{2}$ : 


$$
N_{2}\left(h+\sqrt{\sigma_{1}^{2} \tau_{1}}, l+\sqrt{\sigma_{1}^{2} \tau_{1}+\sigma_{2}^{2} \tau_{2}} ; \rho\right) .
$$

Let's convert the sum: $l+\sqrt{\sigma_{1}^{2} \tau_{1}+\sigma_{2}^{2} \tau_{2}}$. We put the value of $l$ (see formula (10.4), Appendix 10) and get the fraction:

$$
\begin{array}{r}
\frac{\ln \frac{V^{v}}{I_{2}^{v}}+r \tau-\frac{1}{2}\left(\sigma_{1}^{2} \tau_{1}+\sigma_{2}^{2} \tau_{2}\right)}{\sqrt{\sigma_{1}^{2} \tau_{1}+\sigma_{2}^{2} \tau_{2}}} \frac{+\left(\sigma_{1}^{2} \tau_{1}+\sigma_{2}^{2} \tau_{2}\right)}{\sqrt{\sigma_{1}^{2} \tau_{1}+\sigma_{2}^{2} \tau_{2}}} \\
\frac{\ln \frac{V^{v}}{I_{2}^{v}}+r \tau+\frac{1}{2}\left(\sigma_{1}^{2} \tau_{1}+\sigma_{2}^{2} \tau_{2}\right)}{\sqrt{\sigma_{1}^{2} \tau_{1}+\sigma_{2}^{2} \tau_{2}}}
\end{array}
$$

In the obtained fraction the parameter $\sigma_{2}$ enters both the numerator and denominator. This explains the contradictory influence of $\sigma_{2}$ on the value of the compound call option. Furthermore, the parameter $\sigma_{2}$ enters the formula for calculating the compound call option [see (10.1) with a positive sign (the first component) or a negative one (the second component)]. Thus, the increase of $\sigma_{2}$ in the first component is compensated by its growth in the second component $N_{2}$. However, the parameter $\sigma_{2}$ influences the venture fund's decision about its investment as it is a parameter of the equation (10.2).

When calculating the compound call option's value (see formula (10.1)) it is necessary to calculate the two-dimensional standard normal distribution functions:

$$
N_{2}\left(h+\sqrt{\sigma_{1}^{2} \tau_{1}}, l+\sqrt{\sigma_{1}^{2} \tau_{1}+\sigma_{2}^{2} \tau_{2}} ; \rho\right), \mathrm{N}_{2}(\mathrm{~h}, \mathrm{l} ; \rho)
$$

as well as the standard normal distribution function $N_{1}(h)$. The two-dimensional normal distribution function is defined by the probability density $f(x, y)$ :

$$
\begin{gathered}
f(x, y)=\frac{1}{2 \pi \sigma_{x} \cdot \sigma_{y} \sqrt{1-\rho^{2}}} \exp \left\{-\frac{1}{2\left(1-\rho_{x, y}{ }^{2}\right)} .\right. \\
\left.\cdot\left[\frac{(x-a)^{2}}{\sigma_{x}^{2}}-2 \rho \cdot \frac{(x-a) \cdot(y-b)}{\sigma_{x} \cdot \sigma_{y}}+\frac{(y-b)^{2}}{\sigma_{y}^{2}}\right]\right\}, \ldots \ldots \ldots . .
\end{gathered}
$$

where $a, b$ are mathematical expectations of stochastic variables $x, y ; \sigma_{x}, \sigma_{y}$ are the mean square deviations of stochastic variables $x, y$; $\rho_{x, y}$ is the correlation coefficient of the stochastic variables $x$ and $y$.

The normal distribution with the mathematical expectation 0 and the standard deviation 1 is called the standard normal distribution. The two-dimensional standard normal distribution function $F(x, y)$ takes the form:

$$
F(x, y)=\frac{1}{2 \pi \sqrt{1-\rho^{2}}} \int_{-\infty}^{h} \int_{-\infty}^{l} e^{-\frac{1}{2\left(1-\rho^{2}\right)} \cdot\left(x^{2}-2 \rho x y+y^{2}\right)} d x d y
$$

where $(x, y)$ is a two-dimensional random variable; $\rho_{x, y}$ is the correlation coefficient of the random variables $x$ and $y$. The calculation of the two-dimensional standard normal distribution functions including double integrals can be made using the Maple 14 program package. The one-dimensional standard normal distribution function can be calculated using the Microsoft Excel statistical function.

\section{Results and Discussion}

The author's modification of the real options method for determining the valuation of venture capital investments from the venture fund's position was approbated using data from a real venture project in the industrial sector in Russia. The data from this real company were used to construct a financial model, to make calculations and to draw conclusions. The company's management kindly provided us with the initial data for our calculations, with the condition that we will not disclose the company's name and the name of its products.

This company uses innovations in its manufacturing process and is going to implement an innovative project. The core purpose of this project is to organize the production 
of its innovative products using its own production facilities. The project will increase the company's profits, as the increase in its production capacity will ensure the growth of sales associated with its introduction of new products onto the market, and increase the market share of its existing products.

The total amount of financing required from external sources to implement the project is $232,000,000$ Rubles $(7,282,000$ USD). Since the subject of our analysis is the venture fund let us consider the financing of the project by the venture fund only. It is assumed that the venture fund will invest on a staged basis: $35,000,000$ Rubles $(1,100,000$ USD) in 2009 and 197,000,000 Rubles (6,182,000 USD) in 2010. The company-initiator of the project in its turn will invests the following resources: Its intangible assets (Russian, European and American patents), a well-known brand name, the know-how (technology and formulation of the products), its unique equipment (the company-initiator was actively involved in the development of this equipment, with the know-how being partly realized in this equipment). The cash flow forecast for the entire innovative project is presented in Appendix 1. The calculated indicators of the economic efficiency of the entire project by the traditional discounted cash flow method (the NPVmethod) are given in Appendix 2. We have appraised the efficiency of the innovative project from the point of view of the venture fund by the traditional method using the NPV method (a standard calculation) and using the real options method.

Let us determine the innovative project efficiency from the viewpoint of the venture fund by the traditional NVP method (a standard calculation). From practical experience it is known that a venture fund, as a rule, considers the possibility of investing in a project beginning with $25 \%$ plus one share of the investee company (purchasing a blocking parcel of shares). The blocking parcel of shares allows their owners to impose a veto on the Board of Directors' decisions. The venture fund has its own cash flows, which are separate from the general cash flows for the entire project. The composition of the venture fund's financial flows is shown in Table 10.1, Appendix 10.

Let us take eight variant methods of calculating the cash flows of a venture fund. We will calculate the venture fund's cash flows, and the indicators of the fund's investment effectiveness $I R R^{v}$ and $N P V^{v}$, for different variants of the venture fund's share in the equity capital of the investee company. The necessary calculations for every variant will be made using various values of the $P / E$ (PriceEarnings ratio for the shares): For $P / E=2,3$, 4,5 , i.e., the rate of return is 50 percent, 33.3 percent, 25 percent, and 20 percent per year while for $P / E=6$ and 7 the rate of return is 16.7 percent and 14.3 percent per year respectively.

Now let us calculate the cash flows, $N P V^{v}$ and $I R R^{v}$ of the venture fund for the different years of the venture fund's exit from the business: In the years 2018, 2017, 2016, 2015, 2014 and 2013. The venture fund will exit from the investee company in the year when the $I R R^{v}$ values of the venture fund are at their maximum.

The results of the standard calculation of the venture fund's internal rate of return $I R R^{v}$ for the different years of the fund's exit from the business of the investee company with different levels of shareholding by the fund, and different $P / E$ values are given in Appendix 3. This calculation is referred to as the "standard" because it is made without taking into account the value of the compound call option. 
The calculation of the cash flows for the $N P V^{v}$ and $I R R^{v}$ of the venture fund for the different years of "exit" have demonstrated that the venture fund must exit the invested business in 2018 because this year sees the highest internal rate of return for the venture fund. The venture fund will vary its share in the equity capital of the investee company from 25 percent to 49 percent because the current owners of the company want to retain the majority shareholding.

Let us calculate the cash flows of the venture fund and the returns on investment $I R R^{v}$ and $N P V^{v}$ for the year of "exit" 2018 for different levels of shareholding by the venture fund in the equity capital of the investee company (starting from 25\% with a step of $4 \%$, for shareholdings of $29 \%, 33 \%, 41 \%$, $45 \%, 49 \%)$ and different values of the priceearnings ratio for the shares $(P / E=2,3,4,5$, $6,7)$ using the traditional NPV-method. To obtain the net present value for the fund $N P V^{\circ}$ we shall discount the cash flows at the rates of 20 percent, 30 percent and 35 percent, which are widely used for appraising projects in Russia by venture capitalists. The results of the standard calculation of the venture fund's internal rate of return $I R R^{v}$ for the venture fund's exit from the business of the investee company in 2018 are shown in the left part of the Table 4.1, Appendix 4.

Let us analyze the obtained results. We know from our practical experience that acceptable internal rates of return to the fund start at 20 percent. According to our calculations the IRR acceptable to the fund is observed with a 25 percent shareholding, and a $P / E=7: I R R^{v}=20$ percent. Although this return, at only 14.3 percent, is rather low.

With the share of the venture fund in the total equity of the investee company at 29 percent the $I R R^{v}$ equals 20 percent or more only when the $P / E=6\left(I R R^{v}=20 \%\right)$ or the $P / E=7\left(\operatorname{IRR}^{v}=22 \%\right)$. However the obtained internal rates of return, while acceptable, are still rather low ("lower limit"). Acceptable $I R R^{\prime}$ s for the fund with the $P / E=5$ and $P / E$ $=6$ are achieved with a shareholding at either 45 percent or 49 percent: For a 45 percent share at $P / E=5$, the $I R R^{v}=25$ percent, at $P /$

Figure 2. The Correlation between the Internal Rates of Return for the Venture Fund $\left(I R R^{\prime}\right)$ and the Shares Held by the Fund

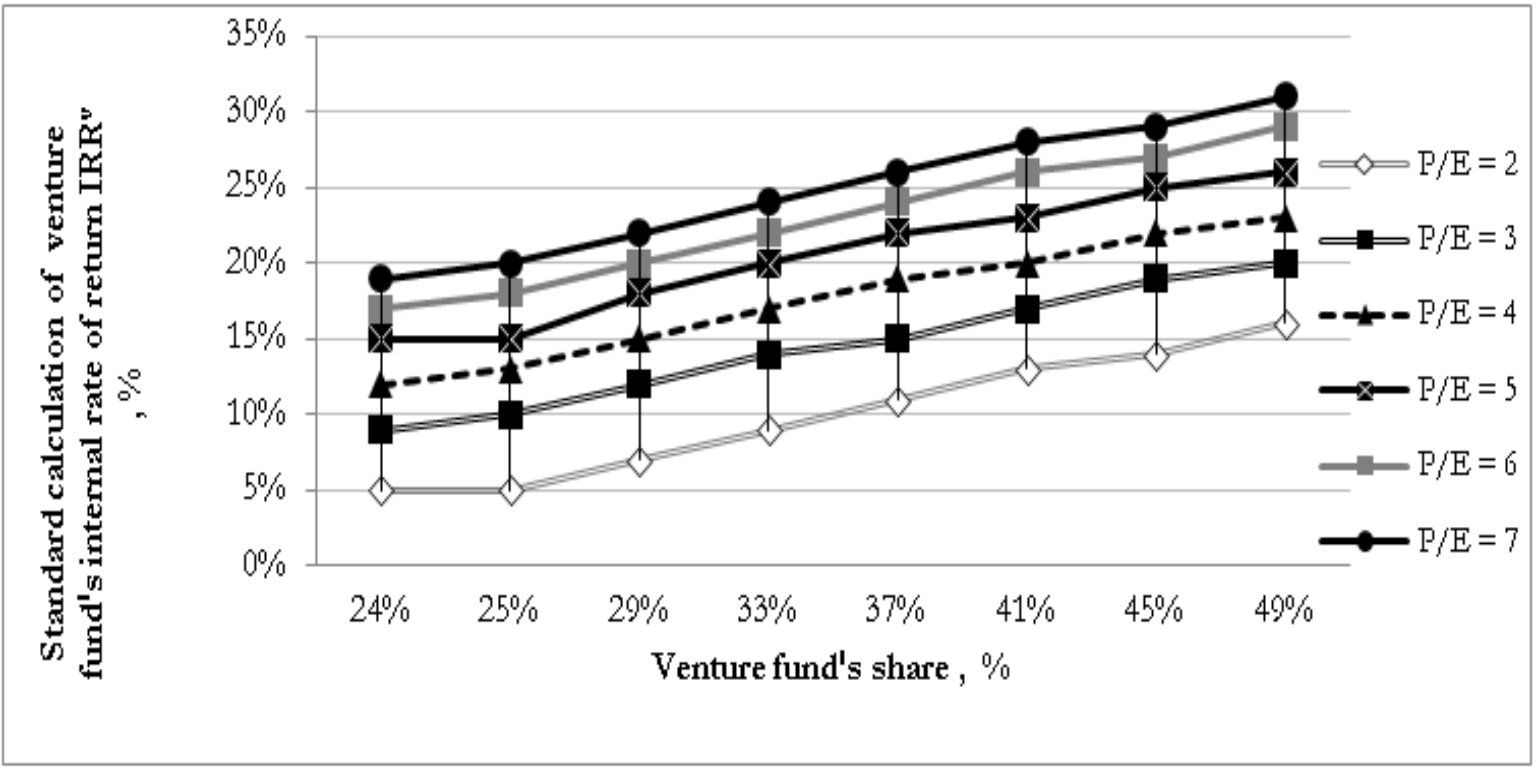


$E=6$, the $I R R^{v}=27$ percent; with a 49 percent shareholding at $P / E=5$, the $I R R^{v}=26$ percent, and at $P / E=6$ the $I R R^{v}=29$ percent. With the fund's shareholding at 41 percent and a $P / E=6$ the $I R R^{v}=26$ percent. Thus, the higher the shareholding of the equity capital of the investee company by the venture fund and the higher the $P / E$ ratio are, the higher is the internal rate of return for the venture fund (see Figure 2).

To calculate the $N P V^{N}$ of the fund let us get the net present value of the fund's cash flows according to the so called "venture" discount rates of 20 percent, 30 percent and 35 percent. With the $I R R^{v}$ of the venture fund less than the discount rate, the $N P V^{v}$ of the venture fund is negative. The results of the standard calculation of the venture fund's $N P V^{v}$ are given in the left part of Table 5.1, Appendix 5.

We see that the positive $N P V^{N}$ of the venture fund starts with the fund's shareholding at 29 percent. With a $P / E=6$, the $N P V^{\prime \prime}$ is 370,000 Rubles; at a $P / E=7$, the $N P V^{v}$ is $27,652,000$ Rubles. With the fund's shareholding at 33 percent, the $N P V^{\prime}$ of the fund is positive only when the $\mathrm{P} / \mathrm{E}=6\left(\mathrm{NPV}^{\prime}\right.$ $=27,892,000$ Rubles) and at $P / E=7$ (NPV $=58,937,000$ Rubles). But the value $P / E=7$, that is, a return of 14.3 percent per year is rather low. Also the positive $N P V^{v}$ of the venture fund for shareholdings of 29 percent, 33 percent, 37 percent, 41 percent, 45 percent and 49 percent is only when the discount rate is 20 percent, which is the bottom limit for a "venture" rate.

For the discount rates of 30 percent and 35 percent the $N P V^{v}$ is negative. The NPV $V^{v}$ is positive with the discount rate equal to 30 percent only when the fund's shareholding is 49 percent and the $P / E=7\left(N P V^{v}=\right.$ $8,825,000$ Rubles). Thus, on true "venture" terms acceptable to the fund, the $N P V^{v}$ of the fund is negative, that is, the project does not provide sufficient returns to the venture fund and should be rejected by the investment committee.

Let us evaluate the innovative project from the venture fund's position using the real option's method. The zero moment is the year 2009: $I_{0}^{v}=$ $35,000,000$ Rubles (according to the cash flow forecast, for the implementation of the project in 2009 an external investment of 35,000,000 Rubles is required) (see Appendix 1). This sum of 35,000,000 Rubles is needed to pay for the administrative expenses and approvals (monitoring of the project, the investment agreement and the land lease); the design (feasibility study (a booklet), a working draft, engineering works, and (gas) energy supplies) and building construction (pre-payment, basement and ground floor construction). Thus, the period of expiration of the compound (external) call option $T_{1}$ is 1 year. The period of expiration of the internal call option $T_{2}$ is 9 years. As we are calculating the value of the compound call option for the venture fund at the moment of investment, that is, at the moment when a decision to invest has been taken, $t$ is the starting moment: $t=0$.

$\tau_{1}=\mathrm{T}_{1}-\mathrm{t}=1$ year; $\tau_{2}=\mathrm{T}_{2}-\mathrm{T}_{1}=9-1=8$ years; $\tau=\mathrm{T}_{2}-\mathrm{t}=\tau_{1}+\tau_{2}=9$ years

Thus, $\tau_{2}=T_{2}-T_{1}$ is the period of time the venture fund stays in the business of the investee company; $\tau_{1}$ is the moment before the fund makes an investment in the company, in return for a share of its charter capital. In the case of the expiration of the compound (external) call option by the venture fund at the moment $T_{1}$ it will make an investment $I_{1}{ }_{1}$ in the amount of $197,000,000$ Rubles. The present value of $I_{1 \text { disc }}$ "discounted will be equal to $184,112,000$ Rubles. 
Let us take one example - for the fund's shareholding of 49 percent and a price-earnings ratio for the shares $P / E=6$, the venture fund's investment at the moment $T_{2}$ will be (see Formula 2):

$I_{2}^{v}=N P A T_{\text {total in } 2018} *$ the fund's share $=$ $591,235,000$ Rubles * $0.49=289,705,000$ Rubles. The present value of $I^{v}{ }_{2 \text { disc }}$ will be 157,580,000 Rubles.

$V^{v}$ is the value of the underlying asset of the internal call option at the moment of its expiration, that is, in the year 2018, at the net present value at the moment of evaluation. The assets the venture fund acquires the right to buy at the moment $T_{1}$ are nothing but the venture fund's income it can get at the moment $T_{2}$ after selling the shares bought at the moment $T_{1}$. The value $V^{v}$ is nothing but the terminal value of the project for the venture fund TER" in the year of the "exit" of the fund from the business of the investee company (in the year 2018). It is the evaluation of the income that the venture fund will get from the sale of its shares. For example, for the fund's shareholding of 49 percent with the price-earnings ratio for the shares $P / E=$ 6 the $V^{v}$ will be:

$$
\begin{aligned}
V^{\nu}= & 485,412,000 \text { Rubles } * 0.49 * 6+ \\
& 47,570,000 \text { Rubles }=1,474,682,000 \\
& \text { Rubles. }
\end{aligned}
$$

The net present value $V^{\delta}$ at the moment zero will be 802,129,000 Rubles.

Let us calculate the compound call option value using formula (10.1) (Appendix 10) for various values of $\sigma_{2}$. Figure 3 shows the graph of the compound call option value's dependence on the $\sigma_{2}$ values. It is seen on the diagram that the compound call option value is practically independent of the $\sigma_{2}$ values.

Figure 4 shows the graph of the dependence of the threshold value of the investee company's equity shares at the moment $T_{p}, V_{T_{1}}$, on the different $\sigma_{2}$ values.

The diagram shows, that with the reduction in uncertainty and risk of the operations of the investee company over the time period $\left(T_{1}, T_{2}\right), \sigma_{2}$, the threshold value of the investee company increases. This could be explained in the following way: According to Black and

Figure 3. The Diagram of the Compound Call Options's Value Dependence on the $\sigma_{2}$ Values

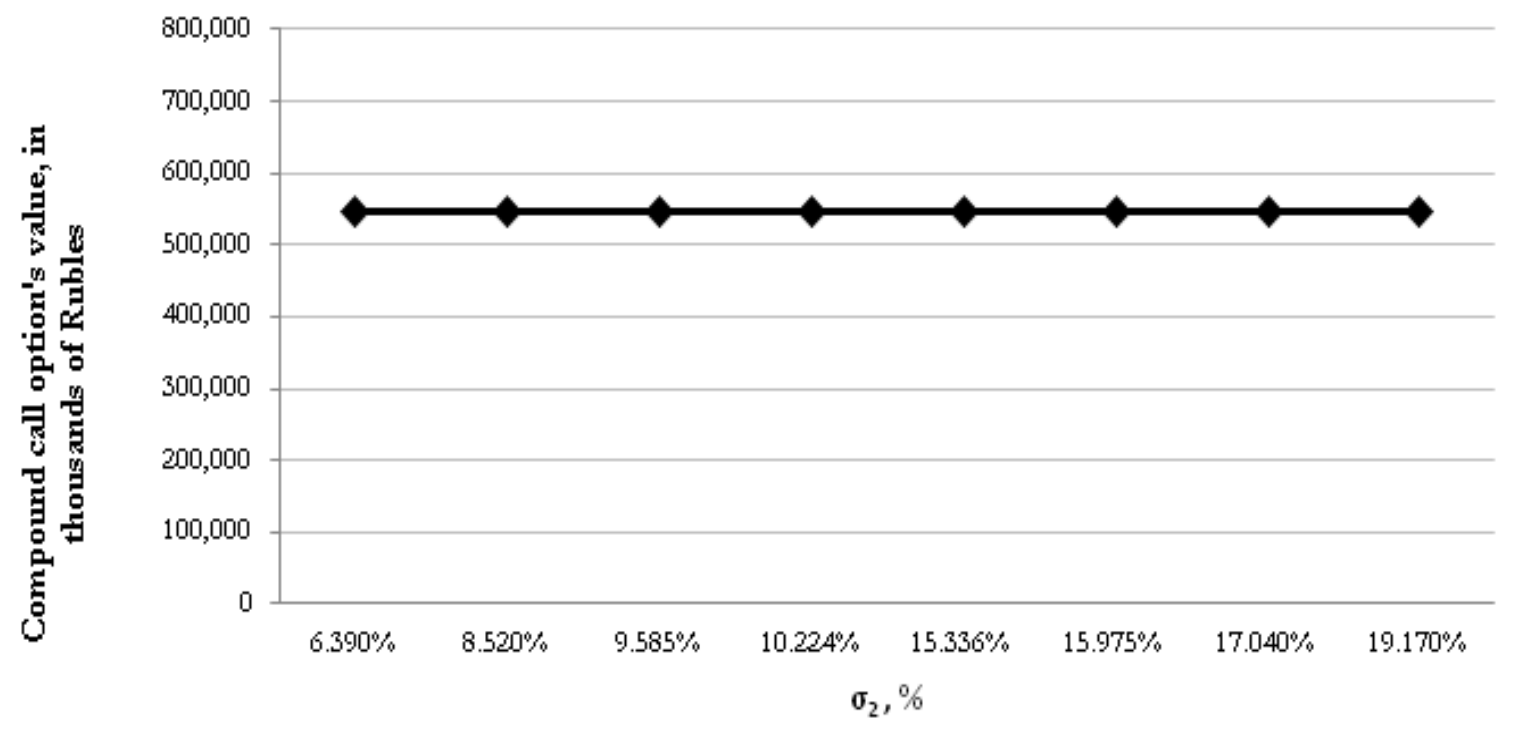


Figure 4. The Diagram of the Dependence of the Threshold Value of the Investee Company's Equity Shares at the Moment $T_{1}$ on the $\sigma_{2}$ Values

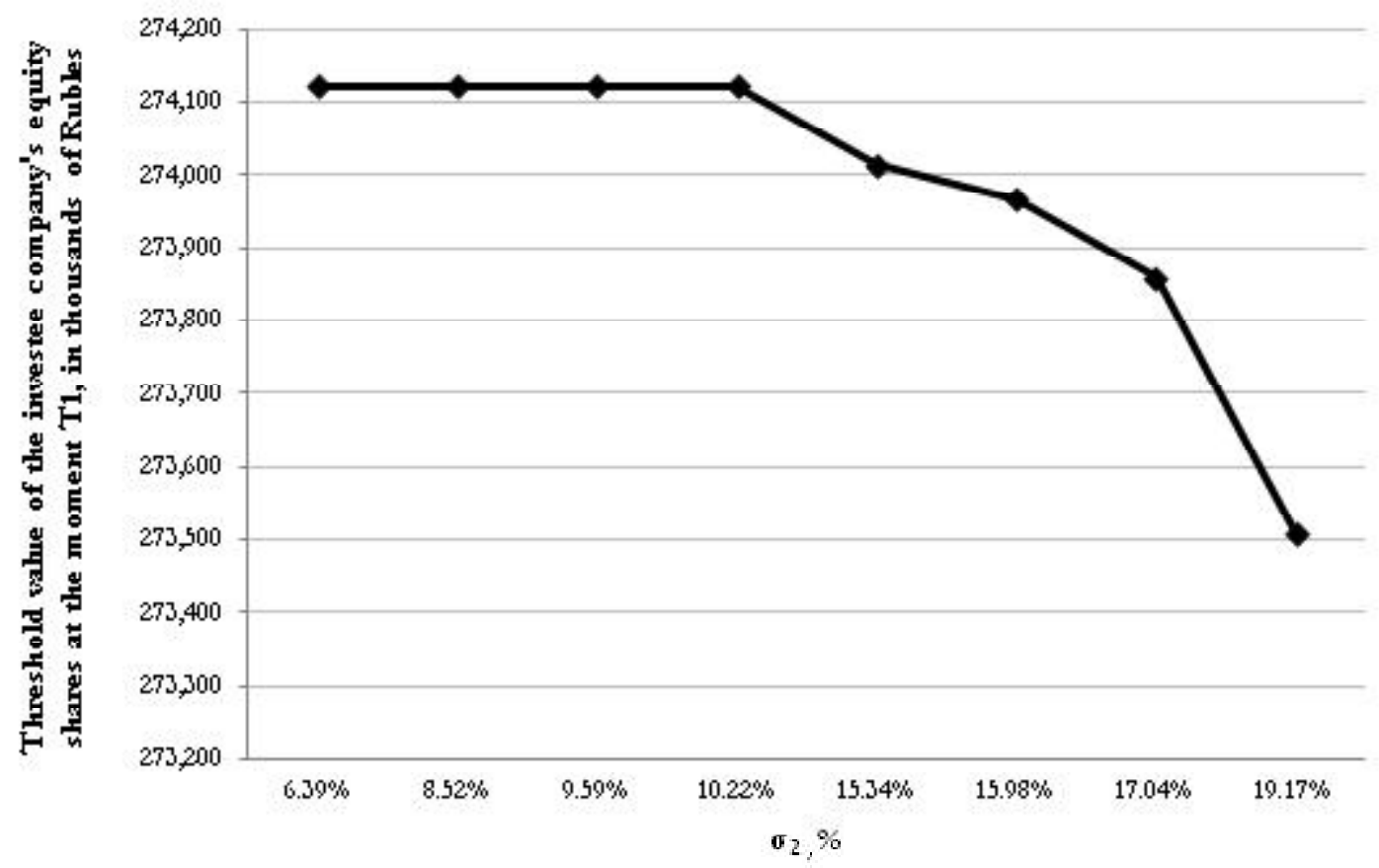

Sholes' formula, with the decrease in the level of uncertainty the option value will decline. In other words, in order to reach the same level of profit with a lower level of uncertainty and at a lower option value at the moment $T_{1}$ the price of the investee company's business should be higher. In this case the decrease in the option value, as a result of the decrease in $\sigma_{2}$ is compensated for by the higher value of the business at the moment $T_{1}$.

This result, in our opinion, shows the contradiction between the traditional methods of investment effectiveness' evaluation and the real options approach. In the first case a positive decision on investment will be more likely in the case of the lower volatility of the underlying asset, and, therefore, with the lower uncertainty of the development of the project. In the second case the high level of uncertainty is considered as a factor contributing to the growth of the assets' value, generated as a result of the investment project's implementation. Since the compound call option value is practically independent of the $\mathrm{o}_{2}$ values, let us take the maximum $o_{2}$ value (the "worst" case) as a value of the riskiness of the investee company's operations during the time period $\left(T_{1}, T_{2}\right)$, under the assumption that the risk level will diminish over time. Thus, $\sigma_{2}=10.22 \%$.

Let us make a variant calculation of the compound call option value for the venture fund with different levels of the fund's shareholdings in the investee company's charter capital. The results of calculating the compound call option values for the different levels of the venture fund's shareholdings are shown in Appendices 6-9. The results of calculating the value of the compound call option for the various shareholdings by the fund in the charter capital of the investee company at different values of $P / E$ are represented in Figure 5. 
Figure 5. The Value of the Compound Call Option for Various Shares of the Fund in the Equity Capital of the Investee Company at Different $P / E s$, in Thousands of Rubles

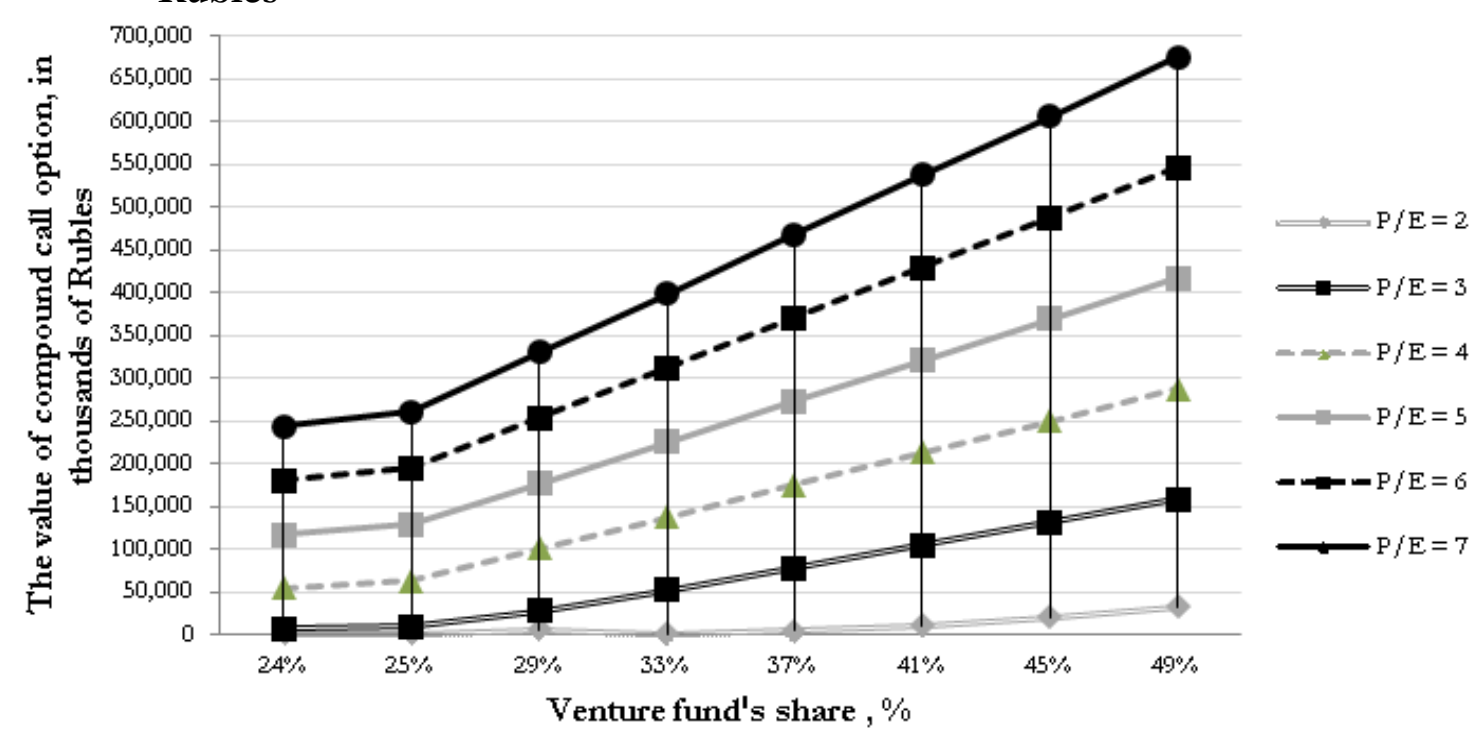

Let us calculate the internal rate of return of the venture fund $I R R^{v}$ and the net present value of the venture fund NPV taking into account the value of the compound call option as an additional cash flow of the venture fund, which appears at the moment $T_{2}$ (in 2018), that is, at the moment of the "exit" of the venture fund from the business of the investee company. The calculated results of the internal rate of return $\left(I R R^{v}\right)$ for the venture fund, taking into account the compound call option value are shown in the right part of Table 4.1, Appendix 4 . The calculated results of the net present value for the venture fund $\left(N P V^{\prime}\right)$, taking into account the compound call option value are shown in the right part of Table 5.1, Appendix 5 .

Let us compare the calculations of $N P V^{\prime}$ and by the traditional method of the discounted cash flow and by taking into account the value of the compound call option. Figure 6 represents the dependence of the internal rate of return of the venture fund on the fund's shareholding in the standard calculation.
Figure 7 shows the dependence of the internal rate of return of the venture fund on the fund's shareholding in calculations taking into account the value of the compound call option.

Figure 8 shows the net present value of the venture fund with $49 \%$ of the charter capital of the investee company at various $\mathrm{P} / \mathrm{E}$ values and the discount rate at 20 percent. Figure 9 demonstrates the net present value of the venture fund with $49 \%$ of the charter capital at various $P / E$ values and the discount rate at 35 percent. The standard calculation of the internal rate of return of the venture fund and the calculation with the real option are presented in Figure 10.

So, we can observe that when in corporating the estimate of the real option, the internal rate of return and the net present value of the venture fund improve. In the calculations using the real options method, the innovative project has a positive value and should be funded by a venture capital investor. 
Figure 6. The Dependence of the Internal Rate of Return of the Venture Fund IRR on the Fund's Share (A Standard Calculation)

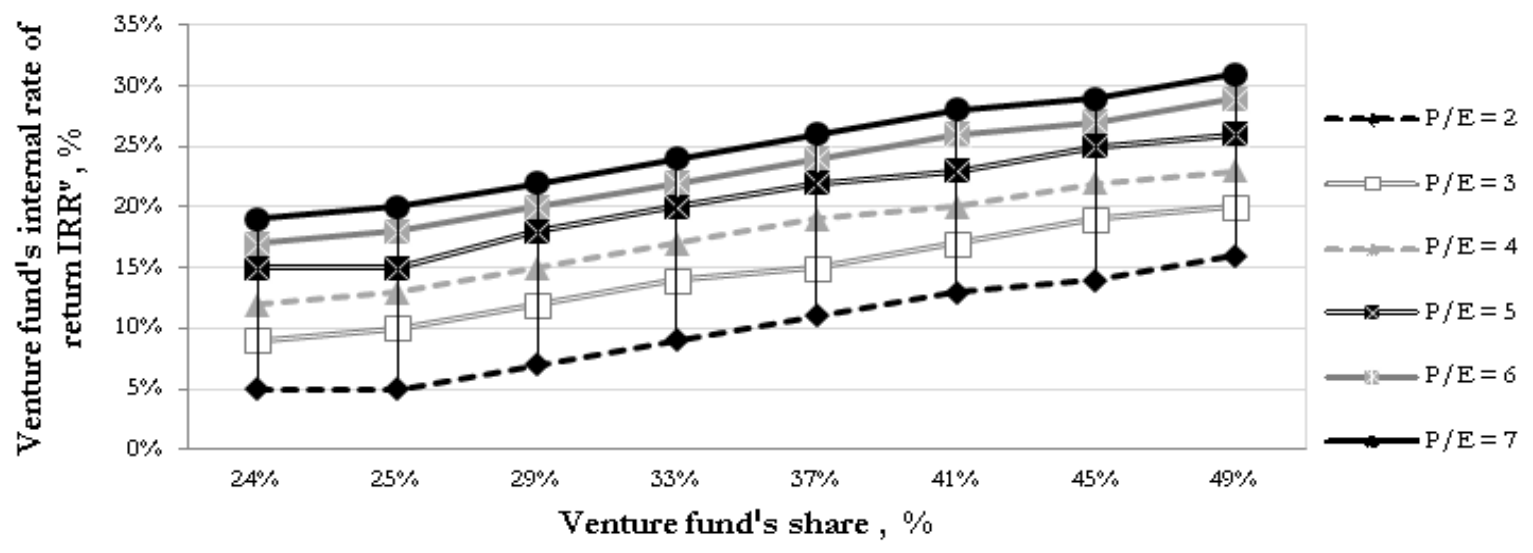

Figure 7. The Dependence of the Internal Rate of Return of the Venture fund $I R R^{v}$ on the Fund's Share (A Calculation Taking Into Account the Value of the Compound Call Option)

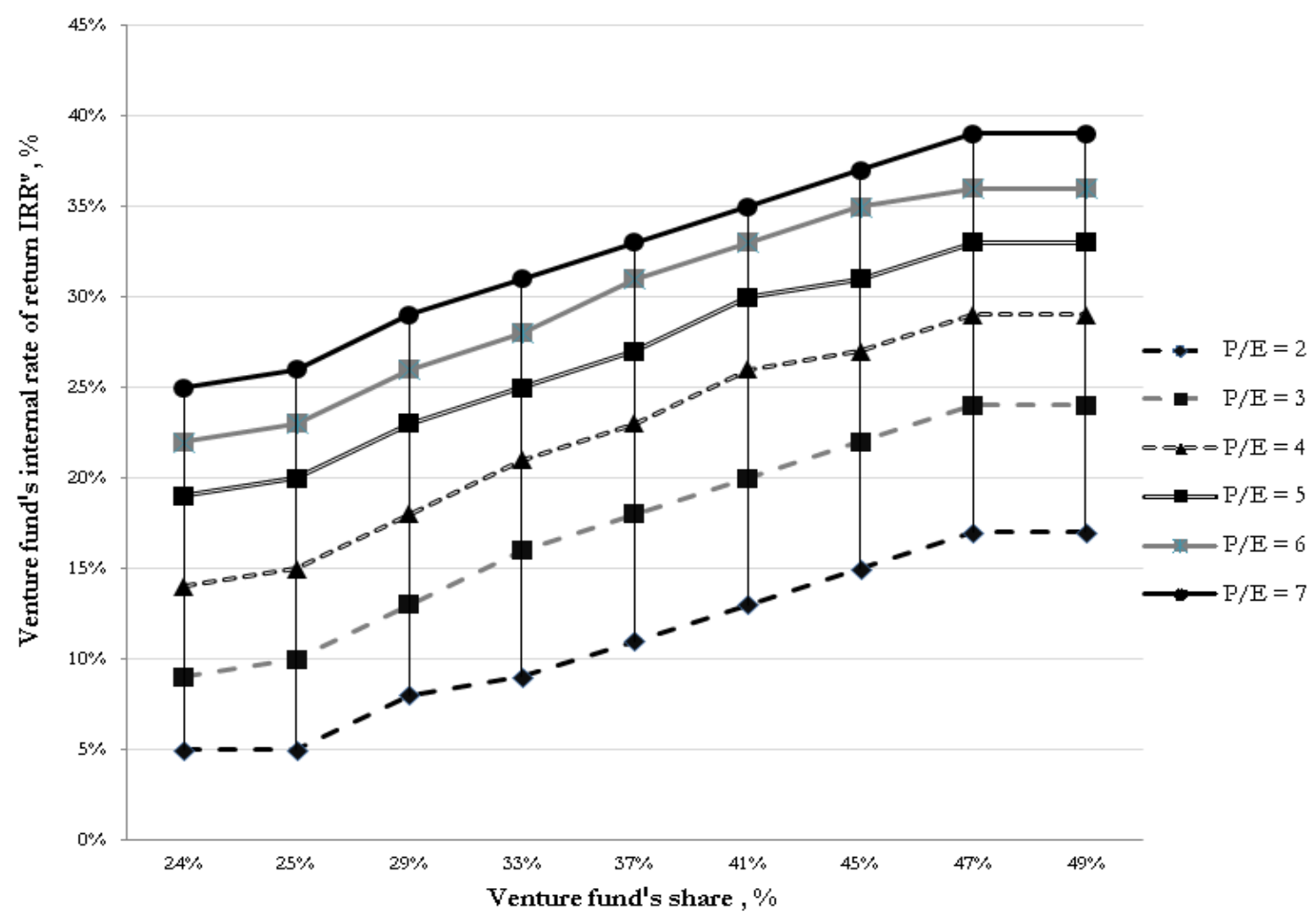


Figure 8. $\boldsymbol{N} \boldsymbol{P} \boldsymbol{V}^{\boldsymbol{N}}$ of the Venture Fund with 49 Percent of the Equity Capital at Various $\boldsymbol{P} /$ $E$ Values and the Discount Rate at 20 percent

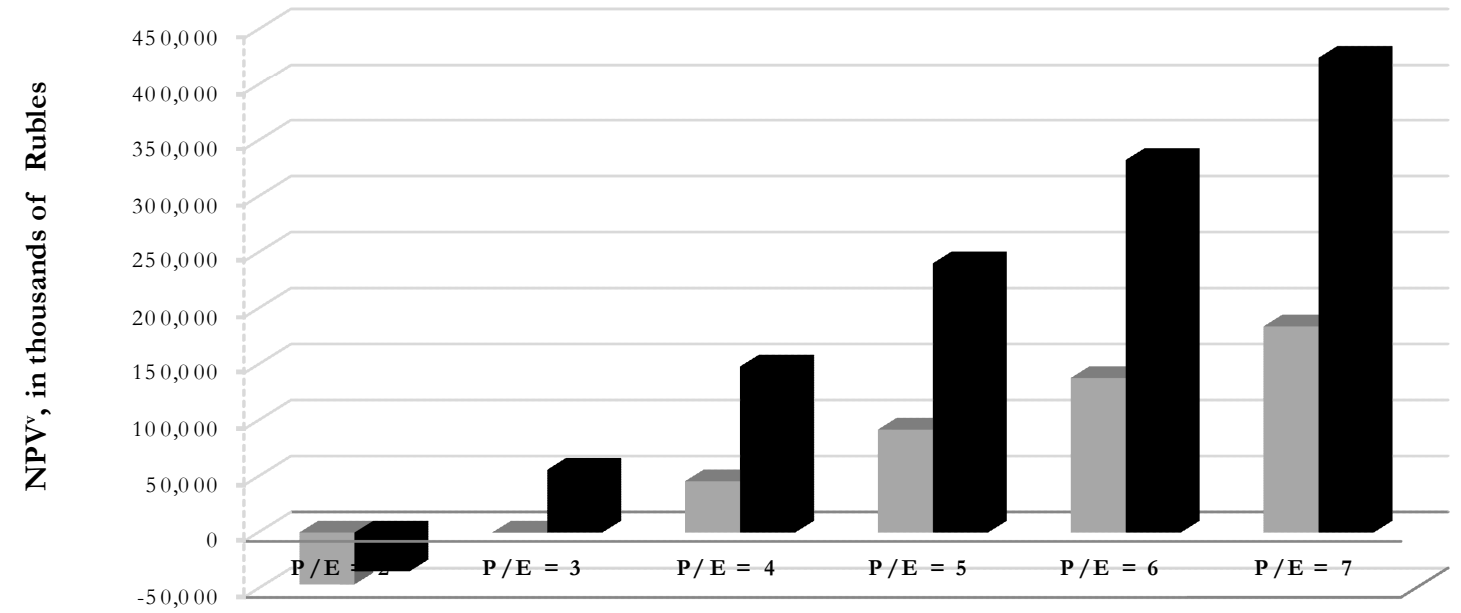

standard calculation of N PVv (in thousands of Rubles)

- calculation of NPVv taking in to account the value of the compound call option (in thousands of Rubles)

Figure 9. $N P V^{W}$ of the Venture Fund with 49 percent of the Equity Capital at Various $P / E$ Values and the Discount Rate at 35 percent

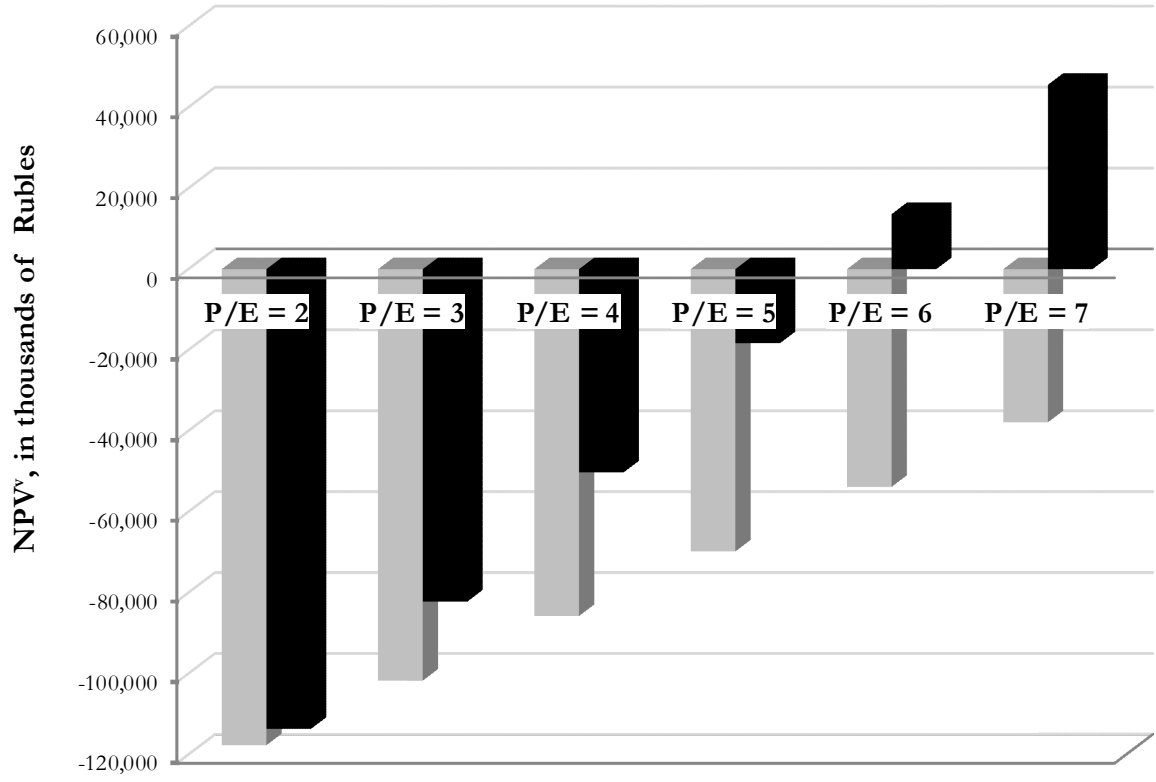

wstandard calculation of NPVv (in thousands of Rubles)

- calculation of NPVv taking into account the value of the compound call option (in thousands of Rubles) 
Figure 10. The Standard Calculation of $I R R^{v}$ and Calculation of $I R R^{v}$ Taking Into Account the Value of the Compound Call option at $P / E=6$ for the Fund's Shareholding at 24 percent and 49 percent

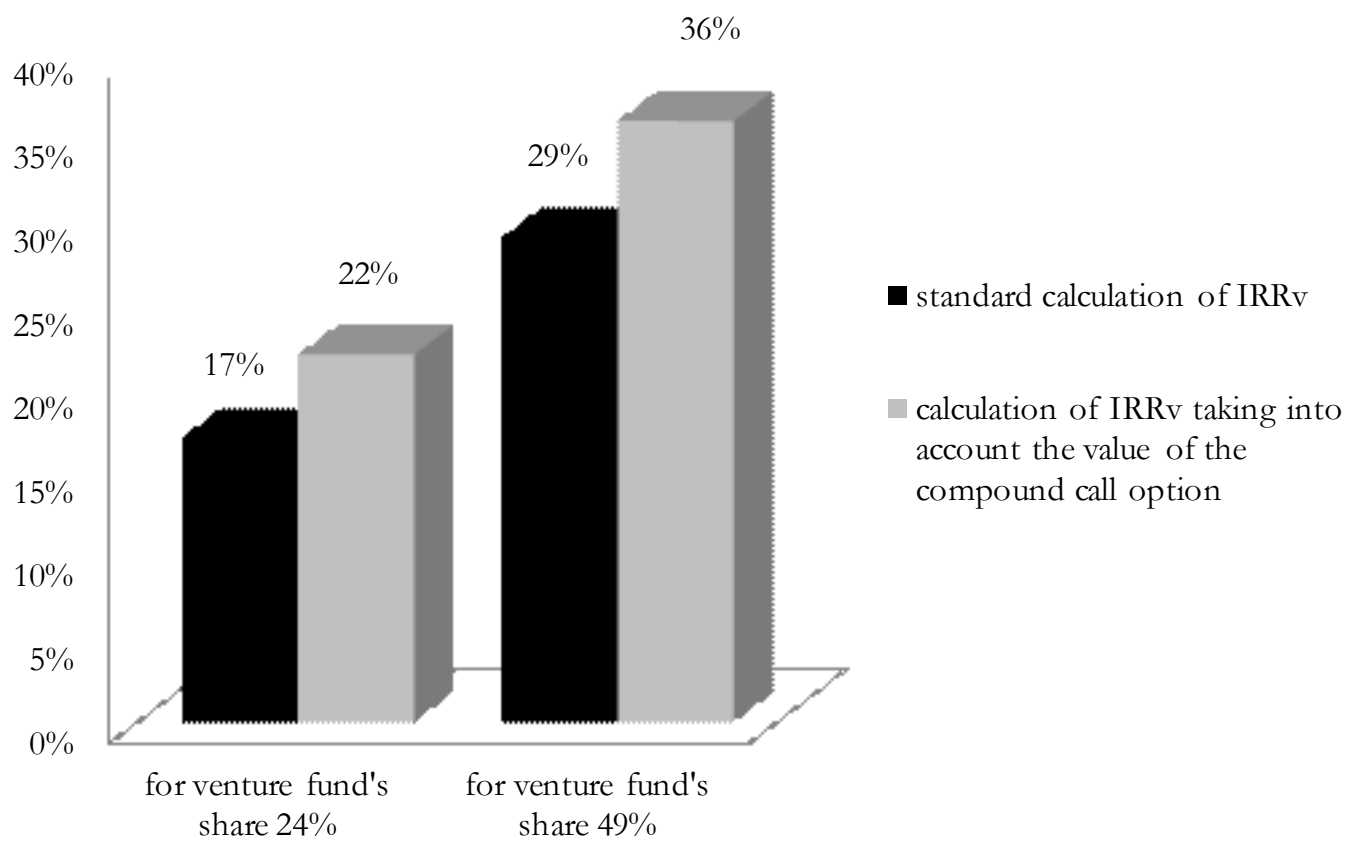

\section{Conclusion}

1. The peculiarities of the application of the real options method for assessing venture capital investments in innovative projects were revealed. The options approach is applicable to the evaluation of innovative projects by venture capitalists, but only taking into account the specific features of venture investments.

2. The author's modification of the real options method from the point of view of its application to the venture capital's financing of innovative projects and its approba- tion using data on venture projects were presented. The entry parameters of the modified version of Geske's formula were construed from the venture fund's position.

3. The practical viability of the author's approach was demonstrated. The use of the real options method raises the accuracy of the estimation and enhances the instruments of the venture fund in evaluating the economic efficiency of innovative projects. This will allow the practical use of the real options method for analyzing projects by venture funds to be expanded. 


\section{References}

Barone-Adesi, G., and R. Whaley. 1987. Efficient analytic approximation of American option values. Journal of Finance 42: 301 - 320.

Black, F., and M. Scholes. 1973. The pricing of options and corporate liabilities. Journal of Political Economy 81 (3): $637-659$.

Botteron, P., and J. Casanova. 2003. Start-ups defined as portfolios of embedded options. Research Paper 85

(May): 1-14. FAME - International Center for Financial Asset Management and Engineering.

Carr, P. 1988. The valuation of sequential exchange opportunities. Journal of Finance 58: 1235 - 1256.

Geske, R. 1979. The valuation of compound options. Journal of Financial Economics 7(1): 63 - 81.

Geske, R., and H.E. Johnson. 1984. The American put option valued analytically. Journal of Finance 39: $1511-1524$.

Gong, P., Z.-W. He, and J.-L. Meng. 2006. Time-dependent Volatility Multi-stage Compound Real Option Model and Application. Journal of Industrial Engineering and Engineering Management, February: 1 - 14.

Herath H. S.B., and C.S. Park 2002. Multi-Stage Capital Investment Opportunities as Compound Real Options. The Engineering Economist 47 (1): 1 - 27.

Hsu, Y. 2002. Staging of venture capital investment: A real options analysis. Working Paper (May), University of Cambridge, JIMS: 1 - 47.

Huixia, Z., and Y. Tao. 2010. Venture capital decision Model Based on Real Option and Investor Behavior. Economics and Management School, Wuhan University, China: 221 - 225.

Jensen, K., and P. Warren. 2001. The use of options theory to value research in the service sector. Re $D$ Management 31 (2): 173 - 180.

Kulatilaka, N., and L. Toschi. 2011. An Integration of the Resource Based View and Real Options Theory for Investments in Outside Opportunities. Available at SSRN: http://ssrn.com/abstract=1541865. Date of access: 02.08.2011.

Lee, J., and A. Paxson. 2000a. Confined exponential approximations for the valuation of American options. Working Paper. Manchester Business School.

Lee, J., and A. Paxson. 2000b. Analytic approximations for American exchange options. Working Paper. Manchester Business School.

Lee, J., and A. Paxson. 2001. Valuation of R\&D real American sequential exchange options. R\&D Management 31 (2): 191 - 201.

Li, Y. 2008. Duration analysis of venture capital staging: A real options perspective. Journal of Business Venturing 23: 497 -5 12.

Li, Y., and J. T. Mahoney. 2011. When are venture capital projects initiated? Journal of Business Venturing 26: $239-254$.

Lin, W. T. 2002. Computing a multivariate normal integral for valuing compound real options. Review of Quantitative Finance and Accounting 18 (2): 185 - 209.

Margrabe, W. 1978. The value of an option to exchange one asset for another. Journal of Finance 33: 177 186. 
NASDAQ Biotechnology Index. URL:http://www.nasdaq.com/dynamic/nasdaqbiotech_activity.stm. Date of access: 09.09.2011.

Perlitz M., T. Peske, and R. Schrank. 1999. Real options valuation: The new frontier in R\&D project evaluation? R\&D Management 29 (3): 255 - 269.

Seppa, T. J., and T. Laamanen. 2001. Valuation of venture capital investments: Empirical evidence. R\&D Management 31: 215 - 230.

Tong, W. T., and Y, Li. 2010. Real options and investment mode: Evidence from corporate venture capital and acquisition. Organization Science Forthcoming. Available at SSRN: http://ssrn.com/abstract $=1529692$. Date of access: 23.07.2011.

Vanhaverbeke, W., V. Van de Vrande, and H. Chesbrough. 2008. Understanding the advantages of open innovation practices in corporate venturing in terms of real options. Creativity and Innovation Management 17(4): 251 - 258.

Wadhwa, A., and C. Phelps. 2010. An option to ally: A Dyadic Analysis of Corporate Venture Capital Relationships". In Proceedings of the Atlanta Competitive Advantage Conference (ACAC), 02/2010. DOI: 10.2139/ssrn.1553322.

Willner, R. 1995. Valuing start-up venture growth options. In Trigeorgis, L. (Ed.), Real Options in Capital Investment. New York: Praeger: 221 - 239. 


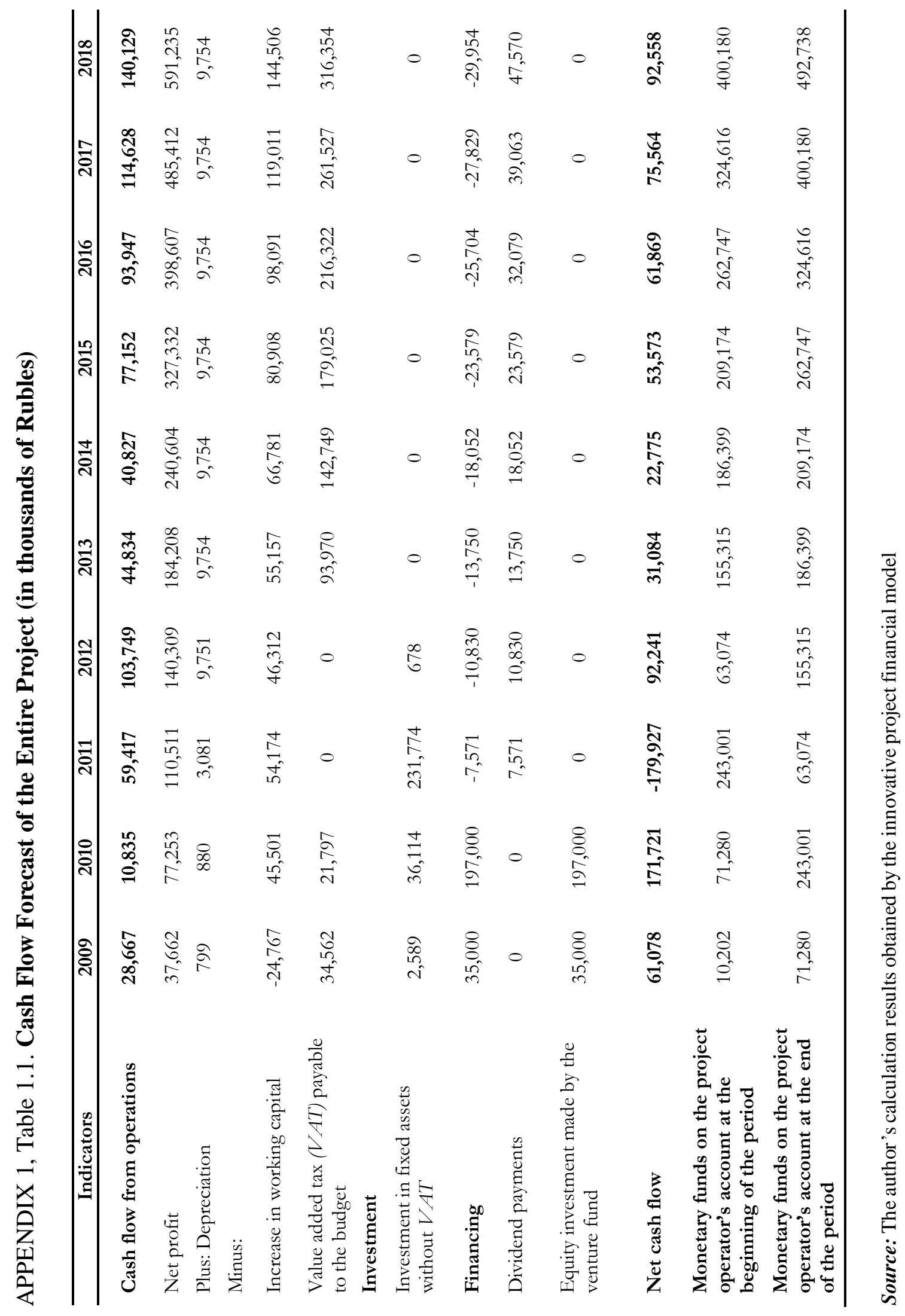




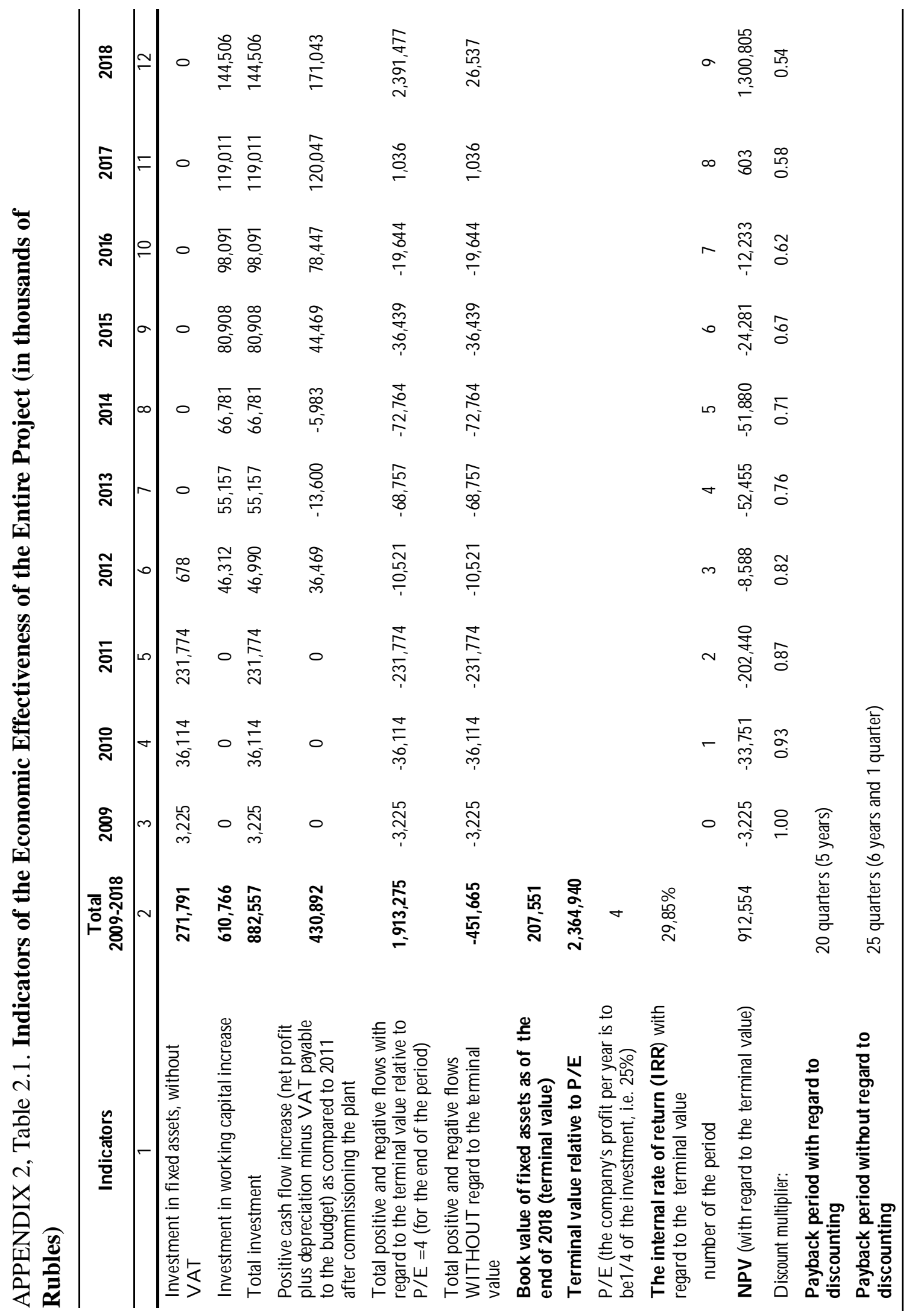


APPENDIX 3, Table 3.1. Venture Fund's Internal Rate of Return IR $\boldsymbol{R}^{\mathbf{v}}$ for Different Years of the Fund's Exit from the Business of the Investee Company, \% (standard calculation)

\begin{tabular}{|c|c|c|c|c|c|}
\hline \multirow{2}{*}{$P / E$} & \multicolumn{5}{|c|}{ Year of fund's exit from the business } \\
\hline & 2018 & 2017 & 2016 & 2015 & 2014 \\
\hline & \multicolumn{5}{|c|}{ Venture fund's share $24 \%$} \\
\hline$P / E=2$ & 5 & 2 & -2 & -8 & -17 \\
\hline$P / E=3$ & 9 & 7 & 4 & -2 & -9 \\
\hline$P / E=4$ & 12 & 10 & 8 & 3 & -3 \\
\hline$P / E=5$ & 15 & 13 & 12 & 7 & 1 \\
\hline$P / E=6$ & 17 & 16 & 15 & 11 & 6 \\
\hline \multirow[t]{2}{*}{$P / E=7$} & 19 & 18 & 17 & 14 & 9 \\
\hline & \multicolumn{5}{|c|}{ Venture fund's share $25 \%$} \\
\hline$P / E=2$ & 5 & 3 & -1 & -8 & -16 \\
\hline$P / E=3$ & 10 & 7 & 4 & -1 & -8 \\
\hline$P / E=4$ & 13 & 11 & 9 & 4 & -2 \\
\hline$P / E=5$ & 15 & 14 & 12 & 8 & 2 \\
\hline$P / E=6$ & 18 & 17 & 15 & 11 & 7 \\
\hline \multirow[t]{2}{*}{$P / E=7$} & 20 & 19 & 18 & 15 & 10 \\
\hline & \multicolumn{5}{|c|}{ Venture fund's share $29 \%$} \\
\hline$P / E=2$ & 7 & 5 & 1 & -5 & -13 \\
\hline$P / E=3$ & 12 & 10 & 7 & 2 & -5 \\
\hline$P / E=4$ & 15 & 14 & 12 & 7 & 1 \\
\hline$P / E=5$ & 18 & 17 & 15 & 11 & 6 \\
\hline$P / E=6$ & 20 & 19 & 18 & 15 & 11 \\
\hline \multirow[t]{2}{*}{$P / E=7$} & 22 & 22 & 21 & 18 & 15 \\
\hline & \multicolumn{5}{|c|}{ Venture fund's share $33 \%$} \\
\hline$P / E=2$ & 9 & 7 & 4 & -2 & -10 \\
\hline$P / E=3$ & 14 & 12 & 10 & 5 & -2 \\
\hline$P / E=4$ & 17 & 16 & 14 & 10 & 5 \\
\hline$P / E=5$ & 20 & 19 & 18 & 14 & 10 \\
\hline$P / E=6$ & 22 & 22 & 21 & 18 & 14 \\
\hline \multirow[t]{2}{*}{$P / E=7$} & 24 & 24 & 24 & 21 & 18 \\
\hline & \multicolumn{5}{|c|}{ Venture fund's share $37 \%$} \\
\hline$P / E=2$ & 11 & 9 & 6 & 0 & -7 \\
\hline$P / E=3$ & 15 & 14 & 12 & 7 & 1 \\
\hline$P / E=4$ & 19 & 18 & 16 & 12 & 8 \\
\hline$P / E=5$ & 22 & 21 & 20 & 17 & 13 \\
\hline$P / E=6$ & 24 & 24 & 23 & 21 & 18 \\
\hline$P / E=7$ & 26 & 26 & 26 & 24 & 22 \\
\hline
\end{tabular}


Gadjah Mada International Journal of Business - May-August, Vol. 18, No. 2, 2016

APPENDIX 3, Table 3.1. Continued

\begin{tabular}{|c|c|c|c|c|c|}
\hline \multirow{2}{*}{$P / E$} & \multicolumn{5}{|c|}{ Year of fund's exit from the business } \\
\hline & 2018 & 2017 & 2016 & 2015 & 2014 \\
\hline & \multicolumn{5}{|c|}{ Venture fund's share $41 \%$} \\
\hline$P / E=2$ & 13 & 11 & 8 & 2 & -5 \\
\hline$P / E=3$ & 17 & 16 & 14 & 9 & 4 \\
\hline$P / E=4$ & 20 & 20 & 18 & 15 & 10 \\
\hline$P / E=5$ & 23 & 23 & 22 & 19 & 16 \\
\hline$P / E=6$ & 26 & 26 & 26 & 23 & 21 \\
\hline \multirow[t]{2}{*}{$P / E=7$} & 28 & 28 & 28 & 27 & 25 \\
\hline & \multicolumn{5}{|c|}{ Venture fund's share $45 \%$} \\
\hline$P / E=2$ & 14 & 12 & 10 & 4 & -2 \\
\hline$P / E=3$ & 19 & 17 & 16 & 11 & 6 \\
\hline$P / E=4$ & 22 & 21 & 20 & 17 & 13 \\
\hline$P / E=5$ & 25 & 25 & 24 & 22 & 19 \\
\hline$P / E=6$ & 27 & 27 & 28 & 25 & 23 \\
\hline \multirow[t]{2}{*}{$P / E=7$} & 29 & 30 & 31 & 29 & 28 \\
\hline & \multicolumn{5}{|c|}{ Venture fund's share $49 \%$} \\
\hline$P / E=2$ & 16 & 14 & 11 & 6 & 0 \\
\hline$P / E=3$ & 20 & 19 & 17 & 13 & 9 \\
\hline$P / E=4$ & 23 & 23 & 22 & 19 & 15 \\
\hline$P / E=5$ & 26 & 26 & 26 & 24 & 21 \\
\hline$P / E=6$ & 29 & 29 & 30 & 28 & 26 \\
\hline$P / E=7$ & 31 & 32 & 32 & 31 & 30 \\
\hline
\end{tabular}


APPENDIX 4, Table 4.1. Standard Calculation of the Venture Fund's Internal Rate of Return IRR $\boldsymbol{R}^{v}$ and $I R R^{v}$ Calculations Taking into Account the Value of the Compound Call Option for the Venture Fund's "Exit" from the Business in 2018

\begin{tabular}{|c|c|c|}
\hline $\mathbf{P} / \mathbf{E}$ & $\begin{array}{c}\text { Standard } \\
\text { calculation }\end{array}$ & $\begin{array}{l}\text { Calculation taking into account the } \\
\text { value of the compound call option }\end{array}$ \\
\hline \multicolumn{3}{|c|}{ Venture fund's share $24 \%$} \\
\hline$P / E=2$ & $5 \%$ & $5 \%$ \\
\hline$P / E=3$ & $9 \%$ & $9 \%$ \\
\hline$P / E=4$ & $12 \%$ & $14 \%$ \\
\hline$P / E=5$ & $15 \%$ & $19 \%$ \\
\hline$P / E=6$ & $17 \%$ & $22 \%$ \\
\hline$P / E=7$ & $19 \%$ & $25 \%$ \\
\hline \multicolumn{3}{|c|}{ Venture fund's share $25 \%$} \\
\hline$P / E=2$ & $5 \%$ & $5 \%$ \\
\hline$P / E=3$ & $10 \%$ & $10 \%$ \\
\hline$P / E=4$ & $13 \%$ & $15 \%$ \\
\hline$P / E=5$ & $15 \%$ & $20 \%$ \\
\hline$P / E=6$ & $18 \%$ & $23 \%$ \\
\hline$P / E=7$ & $20 \%$ & $26 \%$ \\
\hline \multicolumn{3}{|c|}{ Venture fund's share $29 \%$} \\
\hline$P / E=2$ & $7 \%$ & $8 \%$ \\
\hline$P / E=3$ & $12 \%$ & $13 \%$ \\
\hline$P / E=4$ & $15 \%$ & $18 \%$ \\
\hline$P / E=5$ & $18 \%$ & $23 \%$ \\
\hline$P / E=6$ & $20 \%$ & $26 \%$ \\
\hline$P / E=7$ & $22 \%$ & $29 \%$ \\
\hline \multicolumn{3}{|c|}{ Venture fund's share $33 \%$} \\
\hline$P / E=2$ & $9 \%$ & $9 \%$ \\
\hline$P / E=3$ & $14 \%$ & $16 \%$ \\
\hline$P / E=4$ & $17 \%$ & $21 \%$ \\
\hline$P / E=5$ & $20 \%$ & $25 \%$ \\
\hline$P / E=6$ & $22 \%$ & $28 \%$ \\
\hline$P / E=7$ & $24 \%$ & $31 \%$ \\
\hline \multicolumn{3}{|c|}{ Venture fund's share $37 \%$} \\
\hline$P / E=2$ & $11 \%$ & $11 \%$ \\
\hline$P / E=3$ & $15 \%$ & $18 \%$ \\
\hline$P / E=4$ & $19 \%$ & $23 \%$ \\
\hline$P / E=5$ & $22 \%$ & $27 \%$ \\
\hline$P / E=6$ & $24 \%$ & $31 \%$ \\
\hline$P / E=7$ & $26 \%$ & $33 \%$ \\
\hline
\end{tabular}




\section{APPENDIX 4, Table 4.1. Continued}

\begin{tabular}{|c|c|c|}
\hline $\mathbf{P} / \mathbf{E}$ & $\begin{array}{c}\text { Standard } \\
\text { calculation }\end{array}$ & $\begin{array}{l}\text { Calculation taking into account the } \\
\text { value of the compound call option }\end{array}$ \\
\hline \multicolumn{3}{|c|}{ Venture fund's share $41 \%$} \\
\hline$P / E=2$ & $13 \%$ & $13 \%$ \\
\hline$P / E=3$ & $17 \%$ & $20 \%$ \\
\hline$P / E=4$ & $20 \%$ & $26 \%$ \\
\hline$P / E=5$ & $23 \%$ & $30 \%$ \\
\hline$P / E=6$ & $26 \%$ & $33 \%$ \\
\hline$P / E=7$ & $28 \%$ & $35 \%$ \\
\hline \multicolumn{3}{|c|}{ Venture fund's share $45 \%$} \\
\hline$P / E=2$ & $14 \%$ & $15 \%$ \\
\hline$P / E=3$ & $19 \%$ & $22 \%$ \\
\hline$P / E=4$ & $22 \%$ & $27 \%$ \\
\hline$P / E=5$ & $25 \%$ & $31 \%$ \\
\hline$P / E=6$ & $27 \%$ & $35 \%$ \\
\hline$P / E=7$ & $29 \%$ & $37 \%$ \\
\hline \multicolumn{3}{|c|}{ Venture fund's share $49 \%$} \\
\hline$P / E=2$ & $16 \%$ & $17 \%$ \\
\hline$P / E=3$ & $20 \%$ & $24 \%$ \\
\hline$P / E=4$ & $23 \%$ & $29 \%$ \\
\hline$P / E=5$ & $26 \%$ & $33 \%$ \\
\hline$P / E=6$ & $29 \%$ & $36 \%$ \\
\hline
\end{tabular}


APPENDIX 5, Table 5.1. Standard Calculation of the Venture Fund's $N \boldsymbol{P} \boldsymbol{V}^{\boldsymbol{V}}$ and $\boldsymbol{N} \boldsymbol{P} \boldsymbol{V}^{\boldsymbol{V}}$ Calculations Taking into Account the Value of the Compound Call Option for the Venture Fund's "Exit" from the Business in 2018, in thousands of Rubles

\begin{tabular}{|c|c|c|c|c|c|c|}
\hline \multirow[t]{2}{*}{$P / E$} & \multicolumn{3}{|c|}{ Standard calculation } & \multicolumn{3}{|c|}{$\begin{array}{l}\text { Calculation taking into account the value of } \\
\text { compound call option }\end{array}$} \\
\hline & $r=20 \%$ & $r=30 \%$ & $r=35 \%$ & $r=20 \%$ & $r=30 \%$ & $r=35 \%$ \\
\hline \multicolumn{7}{|c|}{ Venture fund's share $24 \%$} \\
\hline$P / E=2$ & $-124,346$ & $-145,779$ & - 149,963 & $-124,345$ & $-145,779$ & $-149,962$ \\
\hline$P / E=3$ & $-101,768$ & $-134,794$ & $-142,141$ & $-99,513$ & $-133,696$ & $-141,359$ \\
\hline$P / E=4$ & - 79,189 & $-123,808$ & $-134,319$ & $-59,998$ & $-114,470$ & $-127,670$ \\
\hline$P / E=5$ & $-56,611$ & $-112,822$ & $-126,497$ & $-15,015$ & $-92,583$ & $-112,086$ \\
\hline$P / E=6$ & $-34,033$ & $-101,836$ & $-118,675$ & 30,141 & $-70,612$ & $-96,442$ \\
\hline$P / E=7$ & $-11,455$ & $-90,850$ & $-110,853$ & 75,297 & $-48,640$ & $-80,798$ \\
\hline \multicolumn{7}{|c|}{ Venture fund's share $25 \%$} \\
\hline$P / E=2$ & $-121,228$ & $-144,081$ & $-148,672$ & $-121,226$ & $-144,080$ & $-148,672$ \\
\hline$P / E=3$ & $-97,709$ & $-132,638$ & $-140,525$ & $-94,398$ & $-131,027$ & $-139,377$ \\
\hline$P / E=4$ & $-74,190$ & $-121,194$ & $-132,377$ & $-51,740$ & $-110,271$ & $-124,599$ \\
\hline$P / E=5$ & $-50,671$ & $-109,751$ & $-124,229$ & $-4,794$ & $-87,428$ & $-108,335$ \\
\hline$P / E=6$ & $-27,152$ & $-98,307$ & $-116,081$ & 42,244 & $-64,541$ & $-92,039$ \\
\hline$P / E=7$ & $-3,633$ & $-86,863$ & $-107,933$ & 89,282 & $-41,654$ & $-75,743$ \\
\hline \multicolumn{7}{|c|}{ Venture fund's share $29 \%$} \\
\hline$P / E=2$ & $-108,758$ & $-137,288$ & $-143,512$ & $-106,777$ & $-136,324$ & $-142,826$ \\
\hline$P / E=3$ & $-81,476$ & $-124,014$ & $-134,060$ & $-71,754$ & $-119,283$ & $-130,692$ \\
\hline$P / E=4$ & $-54,194$ & $-110,739$ & $-124,609$ & $-18,466$ & $-93,355$ & $-112,231$ \\
\hline$P / E=5$ & $-26,912$ & $-97,464$ & $-115,157$ & 36,092 & $-66,809$ & $-93,330$ \\
\hline$P / E=6$ & 370 & $-84,190$ & $-105,706$ & 90,656 & $-40,260$ & $-74,427$ \\
\hline$P / E=7$ & 27,652 & $-70,915$ & $-96,254$ & 145,220 & $-13,711$ & $-55,524$ \\
\hline \multicolumn{7}{|c|}{ Venture fund's share $33 \%$} \\
\hline$P / E=2$ & $-96,288$ & $-130,495$ & $-138,351$ & $-95,911$ & $-130,311$ & $-138,221$ \\
\hline$P / E=3$ & $-65,243$ & $-115,389$ & $-127,596$ & $-46,915$ & $-106,472$ & $-121,247$ \\
\hline$P / E=4$ & $-34,198$ & $-100,284$ & $-116,841$ & 14,887 & $-76,401$ & $-99,836$ \\
\hline$P / E=5$ & $-3,153$ & $-85,178$ & $-106,086$ & 76,978 & $-46,190$ & $-78,325$ \\
\hline$P / E=6$ & 27,892 & $-70,073$ & $-95,330$ & 139,068 & $-15,979$ & $-56,815$ \\
\hline$P / E=7$ & 58,937 & $-54,967$ & $-84,575$ & 201,158 & 14,232 & $-35,304$ \\
\hline \multicolumn{7}{|c|}{ Venture fund's share $37 \%$} \\
\hline$P / E=2$ & $-83,818$ & $-123,702$ & $-133,191$ & $-82,358$ & $-122,991$ & $-132,685$ \\
\hline$P / E=3$ & - 49,010 & $-106,765$ & $-121,132$ & $-21,314$ & $-93,289$ & $-111,537$ \\
\hline$P / E=4$ & $-14,202$ & $-89,829$ & $-109,073$ & 48,248 & $-59,443$ & $-87,438$ \\
\hline$P / E=5$ & 20,606 & $-72,892$ & $-97,014$ & 117,864 & $-25,570$ & $-63,320$ \\
\hline$P / E=6$ & 55,415 & $-55,956$ & $-84,955$ & 187,480 & 8,303 & $-39,203$ \\
\hline$P / E=7$ & 90,223 & $-39,019$ & $-72,896$ & 257,096 & 42,175 & $-15,085$ \\
\hline \multicolumn{7}{|c|}{ Venture fund's share $41 \%$} \\
\hline$P / E=2$ & $-71,348$ & $-116,909$ & $-128,030$ & $-67,623$ & $-115,096$ & $-126,740$ \\
\hline$P / E=3$ & $-32,777$ & $-98,141$ & $-114,668$ & 4,474 & - 80,016 & $-101,762$ \\
\hline$P / E=4$ & 5,795 & $-79,374$ & $-101,305$ & 81,607 & $-42,486$ & $-75,041$ \\
\hline$P / E=5$ & 44,366 & $-60,606$ & - 87,943 & 158,749 & $-4,951$ & $-48,315$ \\
\hline$P / E=6$ & 82,937 & $-41,839$ & $-74,580$ & 235,892 & 32,584 & $-21,590$ \\
\hline$P / E=7$ & 121,508 & $-23,071$ & $-61,217$ & 313,034 & 70,118 & 5,135 \\
\hline \multicolumn{7}{|c|}{ Venture fund's share $45 \%$} \\
\hline$P / E=2$ & $-58,878$ & $-110,115$ & $-122,870$ & $-51,649$ & $-106,598$ & $-120,366$ \\
\hline$P / E=3$ & $-16,544$ & $-89,517$ & $-108,203$ & 30,300 & $-66,724$ & $-91,975$ \\
\hline$P / E=4$ & 25,791 & $-68,919$ & $-93,537$ & 114,967 & $-25,528$ & $-62,643$ \\
\hline$P / E=5$ & 68,125 & $-48,320$ & $-78,871$ & 199,636 & 15,668 & $-33,311$ \\
\hline$P / E=6$ & 110,459 & $-27,722$ & $-64,205$ & 284,304 & 56,865 & $-3,978$ \\
\hline$P / E=7$ & 152,793 & $-7,123$ & $-49,538$ & 368,973 & 98,062 & 25,355 \\
\hline \multicolumn{7}{|c|}{ Venture fund's share $49 \%$} \\
\hline$P / E=2$ & $-46,408$ & $-103,322$ & $-117,709$ & $-34,693$ & $-97,622$ & $-113,651$ \\
\hline$P / E=3$ & -310 & $-80,893$ & $-101,739$ & 56,133 & $-53,430$ & - 82,185 \\
\hline$P / E=4$ & 45,787 & $-58,464$ & $-85,769$ & 148,327 & $-8,571$ & $-50,245$ \\
\hline$P / E=5$ & 91,884 & $-36,034$ & $-69,799$ & 240,522 & 36,288 & $-18,306$ \\
\hline$P / E=6$ & 137,982 & $-13,605$ & $-53,830$ & 332,716 & 81,146 & 13,634 \\
\hline$P / E=7$ & 184,079 & 8,825 & $-37,860$ & 424,911 & 126,005 & 45,574 \\
\hline
\end{tabular}


Gadjah Mada Intemational Joumal of Business - MayyAugust, Vd. 18, No 2, 2016

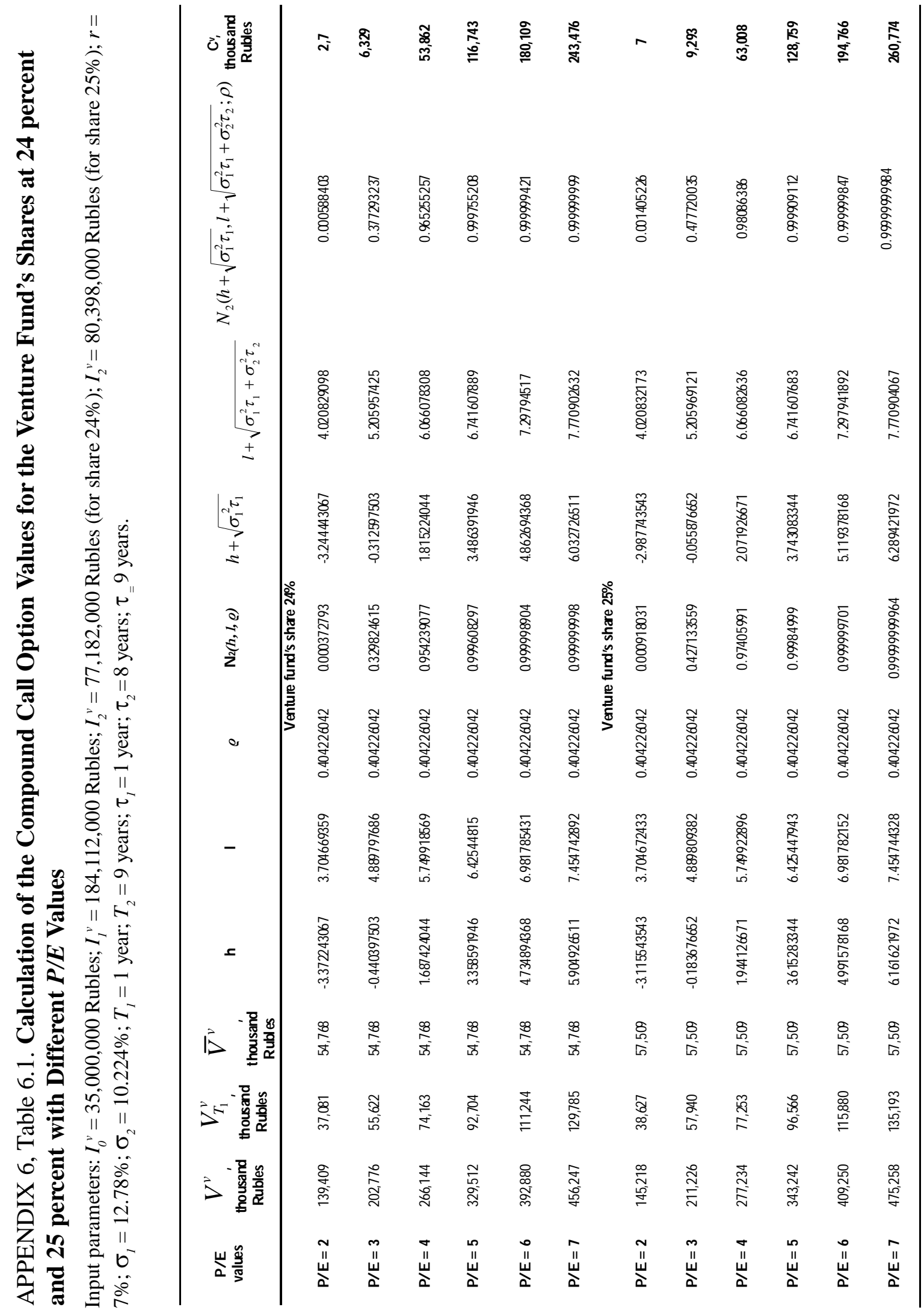




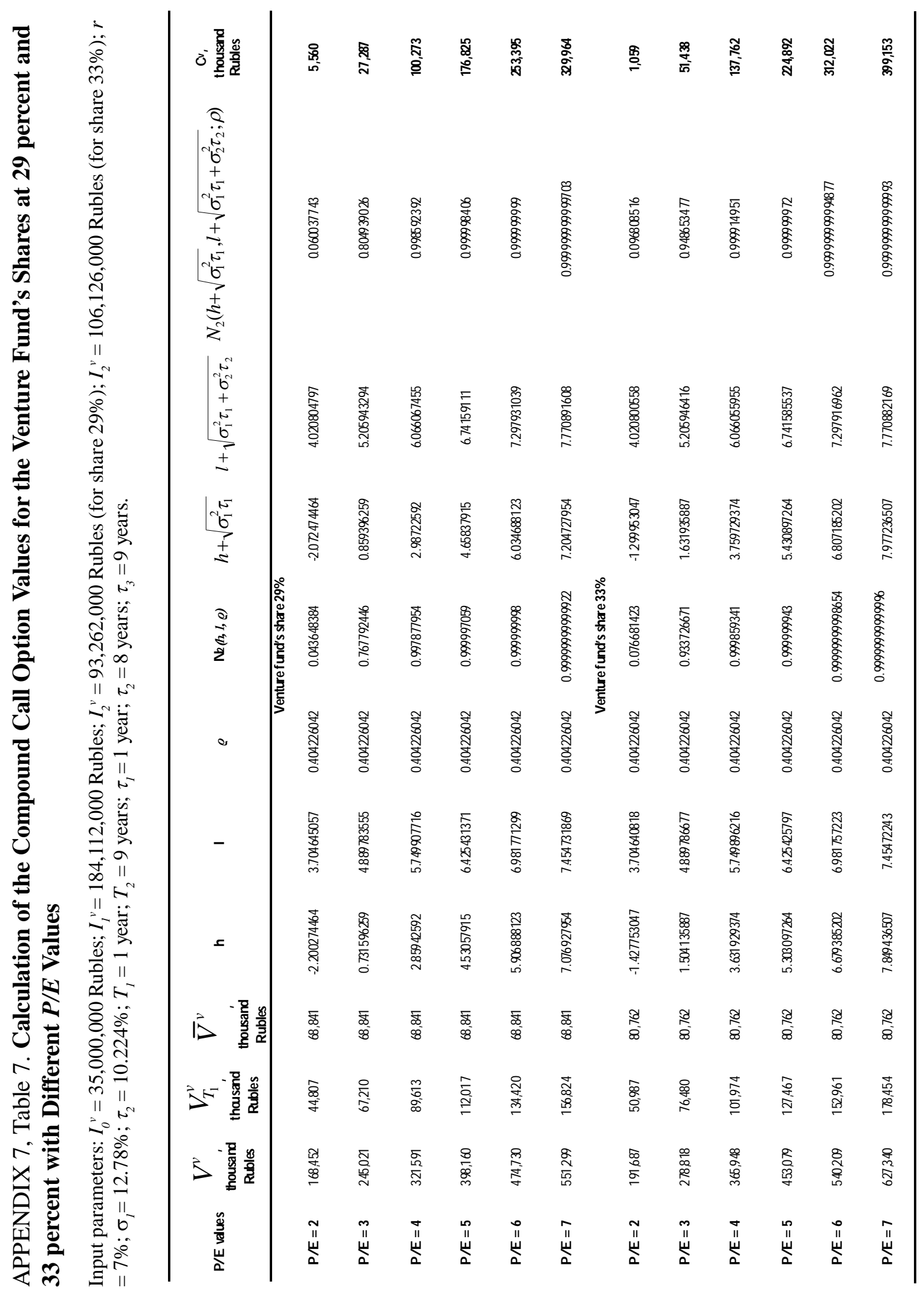




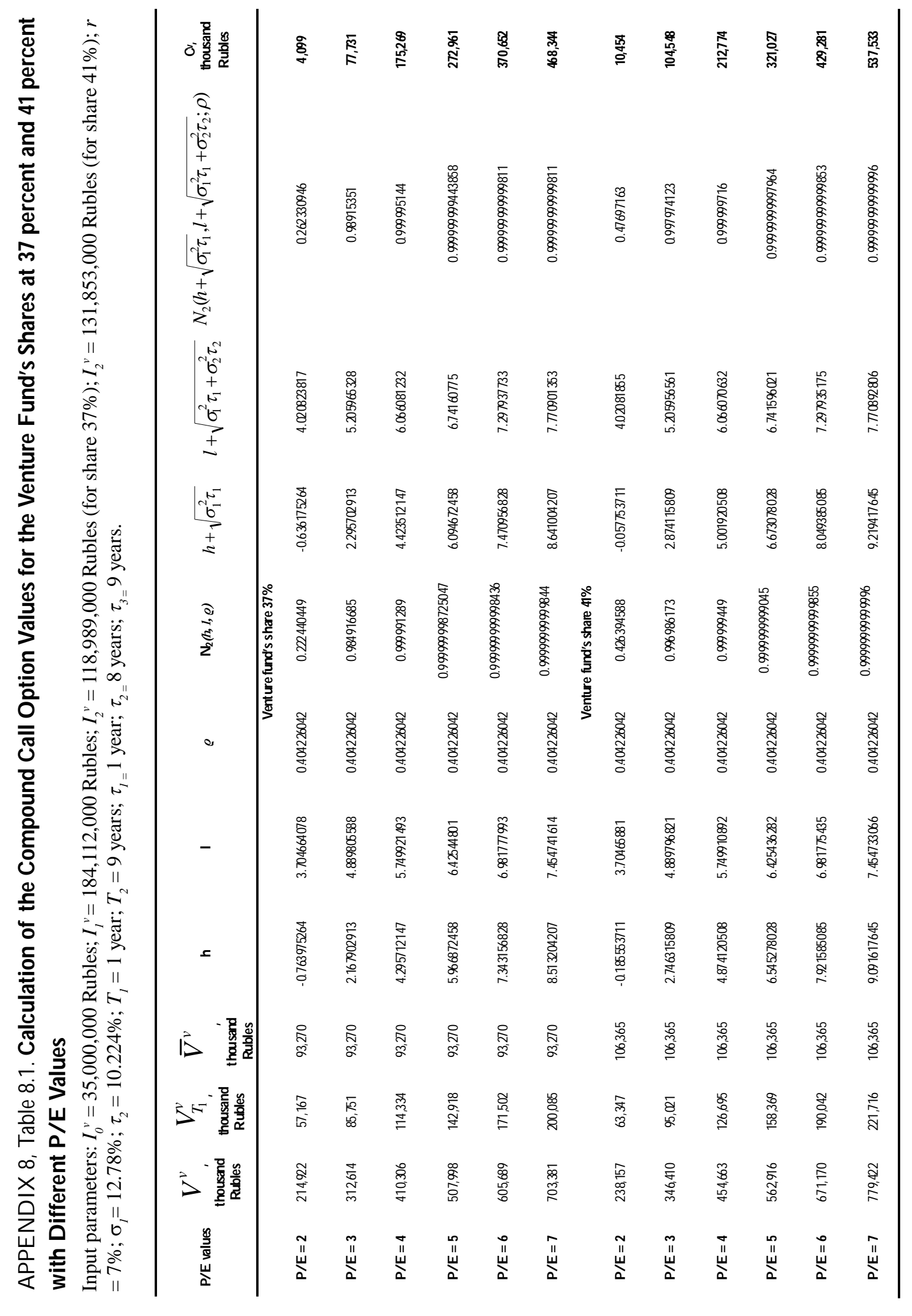




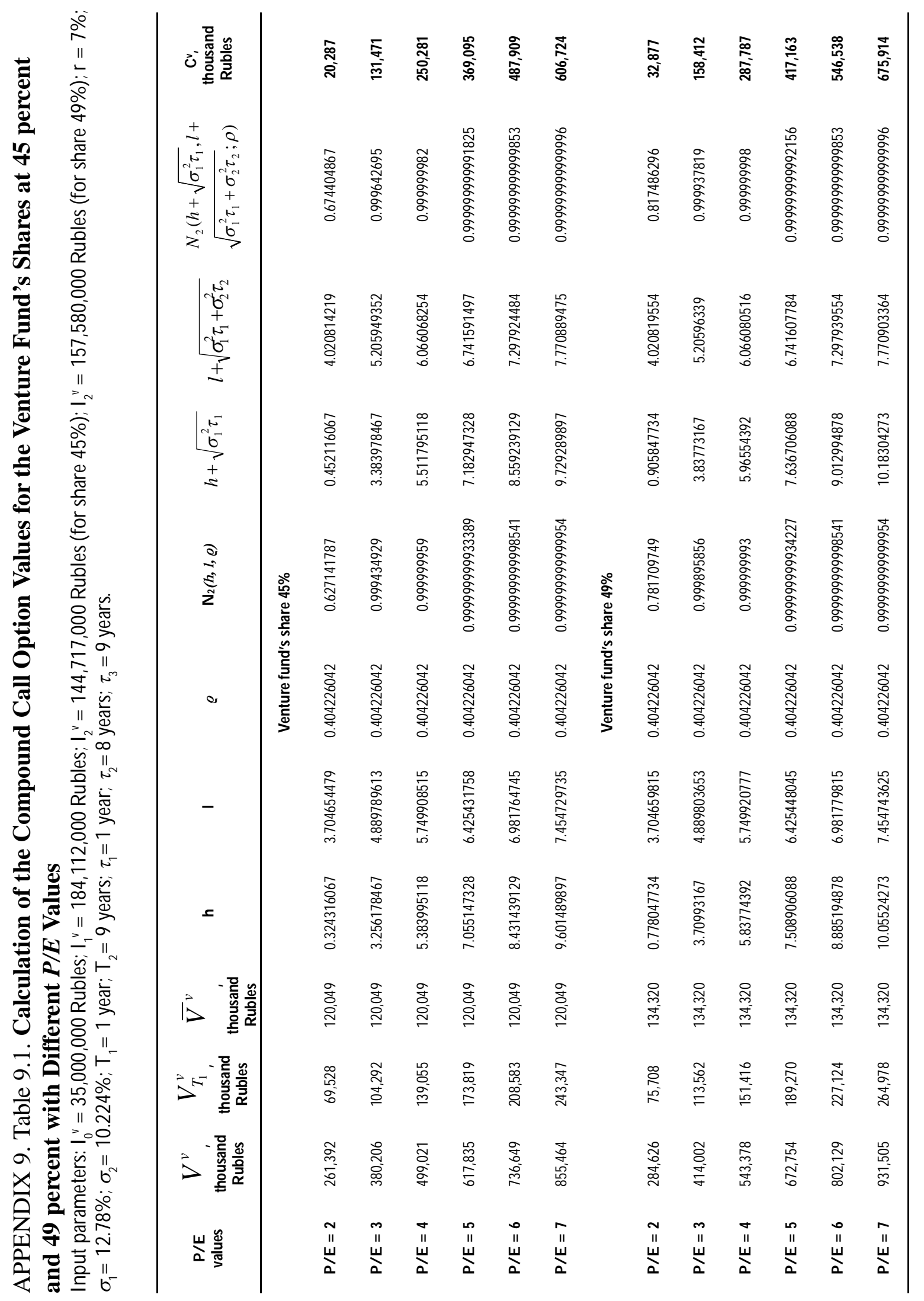


Gadjah Mada International Journal of Business - May-August, Vol. 18, No. 2, 2016

\section{APPENDIX 10, Table 10.1. Definition of the Parameters}

\begin{tabular}{|c|c|}
\hline Parameters & Definition of the parameters \\
\hline $0 \leq D I V^{0}(t)<\infty$ & $\begin{array}{l}\text { dividends paid by the investee company to the venture fund in year } t \text {; positive cash flow } \\
\text { of the venture fund }\end{array}$ \\
\hline $0 \leq S H K^{\prime} \leq 1$ & equity share of the venture fund in the charter capital of the investee company \\
\hline $0 \leq \operatorname{div}(t) \leq 1$ & $\begin{array}{l}\text { part of the investee company's net profit in the previous year }(t-1) \text {, used in year } t \text { for } \\
\text { dividend payout }\end{array}$ \\
\hline $0 \leq \operatorname{PER}^{v}(t)<\infty$ & $\begin{array}{l}\text { interest paid to the venture fund by the investee company in year } t \text { on extended loan; } \\
\text { positive cash flow of the venture fund }\end{array}$ \\
\hline $0 \leq L R^{v}(t)<\infty$ & $\begin{array}{l}\text { repayment of the loan extended by the venture fund to the investee company in year } t \\
\text { positive cash flow of the venture fund }\end{array}$ \\
\hline $0 \leq L^{v}(t)<\infty$ & $\begin{array}{l}\text { the loan extended by the venture fund to the investee company in year } t \text {, negative cash } \\
\text { flow of the venture fund }\end{array}$ \\
\hline $0 \leq I^{v}(t)<\infty$ & $\begin{array}{l}\text { equity investment transferred by the venture fund to the investee company in year } t \text {; } \\
\text { negative cash flow of the venture fund }\end{array}$ \\
\hline $0 \leq \operatorname{TER}^{v}(T)<\infty$ & $\begin{array}{l}\text { terminal value determined as valuation of the returns the venture fund will get in the } \\
\text { last year } T \text { of its investment from the sale of its shares in the investee company; } \\
\text { positive cash flow of the venture fund }\end{array}$ \\
\hline $0<r<\infty$ & discount rate acceptable for the venture fund \\
\hline $0 \leq N P A T(T)<\infty$ & net profit of the investee company in the year $T$ \\
\hline $0 \leq N P A T(T-1)<\infty$ & $\begin{array}{l}\text { net profit of the investee company in the year preceding the "exit" of the venture fund } \\
\text { from the business }\end{array}$ \\
\hline $0<T_{0}<\infty$ & $\begin{array}{l}\text { initial moment of time, when the venture fund purchases the compound call option } \\
\text { (the initial payment which allows starting the project's implementation) }\end{array}$ \\
\hline $0<T_{1}<\infty$ & $\begin{array}{l}\text { moment of time, when venture fund purchases the shares of the investee company } \\
\text { (expiration of the compound (external) call option) }\end{array}$ \\
\hline $0<T_{2}<\infty$ & $\begin{array}{l}\text { moment of time, when venture fund sells its shares of the investee company (expiration } \\
\text { of the internal call option) }\end{array}$ \\
\hline $0<\tau_{1}<\infty$ & $\begin{array}{l}\text { moment before the fund makes an investment into the company in return for a share } \\
\text { of its charter capital }\end{array}$ \\
\hline $0<\tau_{2}<\infty$ & period of time the venture fund stays in the business of the investee company \\
\hline $0<\tau<\infty$ & period of expiration of the internal call option \\
\hline $0<P / E<\infty$ & $\begin{array}{l}\text { price-earnings ratio for the shares, in venture funds' financial calculations often } \mathrm{P} / \mathrm{E}=3 \text {, } \\
4,5,6\end{array}$ \\
\hline $0 \leq V_{t}^{v}<\infty$ & $\begin{array}{l}\text { value of the shares of the investee company, which belongs to the venture fund, at the } \\
\text { moment } t\end{array}$ \\
\hline $0<I_{0}^{v}<\infty$ & $\begin{array}{l}\text { cost of purchasing at the moment } T_{0} \text { the compound call option - is the initial payment } \\
\text { which allows starting the project's implementation }\end{array}$ \\
\hline
\end{tabular}




\begin{tabular}{|c|c|}
\hline Parameters & Definition of the parameters \\
\hline $0 \leq I_{1}^{v}<\infty$ & $\begin{array}{l}\text { price of the purchase of the shares by the venture fund at the moment } T_{1}-\text { is the } \\
\text { purchase of an internal call option for buying an asset at the moment } T_{2} \text { with an } \\
\text { exercise price } I_{2}^{v} \text { (the exercise price of the compound (external) call option). } \\
I_{1}^{v}=V_{\mathrm{T}_{1}} N_{1}\left(l^{*}+\sqrt{\sigma_{2}^{2} \tau_{2}}\right)-I_{2}^{v} e^{-r \tau_{2}} N_{1}\left(l^{*}\right) \ldots \ldots \ldots \ldots . . .(10.2)\end{array}$ \\
\hline $0 \leq I_{2}^{v}<\infty$ & $\begin{array}{l}\text { sum of implicit costs of the venture fund - the loss of its share of the net profit for the } \\
\text { last year of the fund's participation in the business of the investee company (exercise } \\
\text { price of the internal call option) }\end{array}$ \\
\hline$\sigma_{1} \geq 0$ & risk level of operations of the investee company over the time period $\left(0, T_{1}\right)$ \\
\hline$\sigma_{2} \geq 0$ & risk level of operations of the investee company over the time period $\left(T_{1}, T_{2}\right)$ \\
\hline $0 \leq C^{\text {enture fund }}<\infty$ & $\begin{array}{l}\text { value of the compound call option at the current moment } t \text {, which belongs to the } \\
\text { venture fund: }\end{array}$ \\
\hline & $C^{\text {venture fund }}=V^{v} N_{2}\left(h+\sqrt{\sigma_{1}^{2} \tau_{1}}, l+\sqrt{\sigma_{1}^{2} \tau_{1}+\sigma_{2}^{2} \tau_{2}} ; \rho\right)-I_{2}^{v} e^{-r \tau} N_{2}(h, l ; \rho)-I_{1}^{v} e^{-r \tau_{1}} N_{1}(h) \ldots .(10.1)$ \\
\hline $0 \leq V^{n}<\infty$ & $\begin{array}{l}\text { current value of the equity shares of the investee company, which belong to the venture } \\
\text { fund }\end{array}$ \\
\hline$r \geq 0$ & risk-free interest rate \\
\hline $0 \leq N_{2}(h, l ; \rho) \leq 1$ & two-dimensional standard normal distribution function \\
\hline$h, l \in(-\infty ;+\infty)$ & $\begin{array}{l}\text { upper limits of the integrals of the two-dimensional standard normal distribution } \\
\text { function; } \\
\qquad h=\left(\ln \frac{V^{v}}{\bar{V}^{v}}+r \tau_{1}-\frac{1}{2} \sigma_{1}^{2} \tau_{1}\right) / \sqrt{\sigma_{1}^{2} \tau_{1}} \ldots .(10.3) ; \quad l=\left(\ln \frac{V^{v}}{I_{2}^{v}}+r \tau-\frac{1}{2}\left(\sigma_{1}^{2} \tau_{1}+\sigma_{2}^{2} \tau_{2}\right)\right) / \sqrt{\sigma_{1}^{2} \tau_{1}+\sigma_{2}^{2} \tau_{2}} \ldots . .(10.4)\end{array}$ \\
\hline$l^{*} \in(-\infty ;+\infty)$ & $l^{*}=\left(\ln \frac{V_{T_{1}}}{I_{2}^{v}}+r \tau_{2}-\frac{1}{2} \sigma_{2}^{2} \tau_{2}\right) / \sqrt{\sigma_{2}^{2} \tau_{2}} \ldots . . .(10.5) \quad$ value of $l$ at the moment $T_{1}$ \\
\hline$-1 \leq \varrho \leq 1$ & correlation coefficient of stochastic variables; $\rho=\sqrt{\sigma_{1}^{2} \tau_{1} /\left(\sigma_{1}^{2} \tau_{1}+\sigma_{2}^{2} \tau_{2}\right)} \ldots . . .(10.6)$ \\
\hline $0 \leq N_{1}(h) \leq 1$ & one-dimensional standard normal distribution function \\
\hline $\bar{V} \geq 0$ & $\begin{array}{l}\text { such a value of the investee company's equity shares at the moment } T_{1}\left(V_{T_{1}}\right) \text {, which } \\
\text { conforms to the equation }(10.2) \text { (the threshold figure of the value of the investee } \\
\left.\text { company's equity at the moment } T_{1}\right)\end{array}$ \\
\hline $0 \leq V_{T_{1}}^{v}<\infty$ & $\begin{array}{l}\text { value of the investee company's equity shares at the moment } T_{1} \text {, which belong to the } \\
\text { venture fund }\end{array}$ \\
\hline $0 \leq V_{T_{2}}^{v}<\infty$ & $\begin{array}{l}\text { value of the investee company's equity shares at the moment } T_{2} \text {, which belong to the } \\
\text { venture fund }\end{array}$ \\
\hline$I R R^{v} \in(-\infty,+\infty)$ & $\begin{array}{l}\text { internal rate of return for the venture fund, in financial calculations only a positive } I R R^{v} \\
\text { is of interest for an investor }\end{array}$ \\
\hline$N P V^{V} \in(-\infty,+\infty)$ & net present value for the venture fund \\
\hline$N P V_{\text {oppion }}^{V} \in(-\infty,+\infty)$ & $\begin{array}{l}\text { net present value for the venture fund taking into account the value of compound call } \\
\text { option }\end{array}$ \\
\hline
\end{tabular}


Gadjah Mada International Journal of Business - May-August, Vol. 18, No. 2, 2016

APPENDIX 10, Table 10.1. Continued

\begin{tabular}{ll}
\hline \multicolumn{1}{c}{ Parameters } & \multicolumn{1}{c}{ Definition of the parameters } \\
\hline$I R R_{\text {option }}^{v} \in(-\infty,+\infty)$ & $\begin{array}{l}\text { internal rate of return for the venture fund taking into account the value of compound } \\
\text { call option, in financial calculations only a positive } I R R^{v} \text { is of interest to an investor }\end{array}$ \\
$0 \leq N P A T_{\text {total Exit }} \leq \infty$ & $\begin{array}{l}\text { total net profit of the investee company in the year of "exit" of the venture fund from } \\
\text { the invested business }\end{array}$ \\
$0 \leq S \leq 1$ & share of the venture fund in the charter capital of the investee company \\
$I_{1 d i s c}{ }^{v} \geq 0$ & discounted value of $I_{1}{ }^{\nu}$ \\
$I_{2 d i s c} \geq 0$ & discounted value of $I_{2}^{v}$ \\
$0 \leq f(x, y)<+\infty$ & probability density \\
$-\infty<(x, y)<+\infty$ & values of random variables \\
$a, b=0$ (for standard & mathematical expectations of stochastic variables $x, \mathrm{y}$ \\
normal distribution) & \\
$\sigma_{x} \geq 0$ & mean square deviation of stochastic variable $x$ \\
$\sigma_{y} \geq 0$ & mean square deviation of stochastic variable $y$ \\
$-1 \leq \varrho_{x, y} \leq 1$ & correlation coefficient of stochastic variables $x$ and $y$ \\
\hline
\end{tabular}

